UNIVERSIDADE DE SÃO PAULO

ESCOLA DE ENFERMAGEM

RICARDO HENRIQUE SOARES

AVALIAÇÃO PARTICIPATIVA EM UM SERVIÇO DE ATENÇÃO PSICOSSOCIAL EM ÁLCOOL E OUTRAS DROGAS

São Paulo 
RICARDO HENRIQUE SOARES

\section{AVALIAÇÃO PARTICIPATIVA EM UM SERVIÇO DE ATENÇÃO PSICOSSOCIAL EM ÁLCOOL E OUTRAS DROGAS}

Tese apresentada ao Programa de Pós-graduação em Enfermagem da Escola de Enfermagem da Universidade de São Paulo para a obtenção do título de Doutor em Ciências.

Área de concentração: Cuidado em Saúde.

Orientadora: Prof. ${ }^{a}$ Dr. ${ }^{a}$ Márcia Aparecida Ferreira de Oliveira 
AUTORIZO A REPRODUÇÃO E DIVULGAÇÃO TOTAL OU PARCIAL DESTE TRABALHO, POR QUALQUER MEIO CONVENCIONAL OU ELETRÔNICO, PARA FINS DE ESTUDO E PESQUISA, DESDE QUE CITADA A FONTE.

Assinatura:

Data:

Catalogação na Publicação (CIP)

Biblioteca "Wanda de Aguiar Horta"

Escola de Enfermagem da Universidade de São Paulo

Soares, Ricardo Henrique

Avaliação participativa em um serviço de atenção psicossocial em álcool e outras drogas / Ricardo Henrique Soares. - São Paulo, 2017. I Ricardo Henrique Soares. São Paulo, 2017. $95 \mathrm{p}$.

Tese (Doutorado) - Escola de Enfermagem da Universidade de São Paulo.

Orientadora: Prof. ${ }^{\text {a }}$ Dr. ${ }^{\text {a }}$ Márcia Aparecida Ferreira de Oliveira Área de concentração: Cuidado em Saúde

1. Pesquisas sobre serviços de saúde 2. Transtornos relacionados ao uso de substâncias 3. Serviços comunitários de saúde mental 4. Satisfação pessoal. I. Título. 
Nome: Ricardo Henrique Soares

Título: Avaliação participativa em um serviço de atenção psicossocial em álcool e outras drogas

Tese apresentada ao Programa de Pós-graduação em Enfermagem da Escola de Enfermagem da Universidade de São Paulo para obtenção do título de Doutor em Ciências.

Aprovada em:

\section{Banca Examinadora}

Orientador: Prof. Dr.

Instituição: Assinatura:

Prof. Dr.

Instituição:

Julgamento:

Assinatura:

Prof. Dr.

Julgamento:

Instituição:

Assinatura:

Prof. Dr.

Instituição:

Julgamento:

Assinatura:

Prof. Dr.

Instituição:

Julgamento:

Assinatura:

Prof. Dr.

Instituição:

Julgamento:

Assinatura:

Título. 


\section{DEDICATÓRIA}

Dedico o presente trabalho à minha sobrinha Alice Soares Rebouças. 


\section{AGRADECIMENTOS}

Agradeço a confiança e o apoio a mim depositados por todas as pessoas que favoreceram a realização do presente estudo, especialmente à minha orientadora, aos demais professores da Escola de Enfermagem da Vniversidade de São Paulo, aos colegas do Grupo de Estudos em Álcool e Drogas, aos participantes da presente pesquisa, aos meus familiares e aos meus amigos.

Obrigado a todos! 
"Segundo a interpretação de Horkheimer e Adorno, já na Odisséia, quando Vlisses escuta amarrado o canto das sereias enquanto seus companheiros remam de ouvidos tampados, pode se reconhecer a separação do mundo do prazer e do trabalho.

Segundo o Método da Roda, todos poderiam ter feito a viagem escutando a música, remando e, por que não?, cantando." (Campos, 2005a) 
Soares, RH. Avaliação participativa em um serviço de atenção psicossocial em álcool e outras drogas [tese]. São Paulo: Escola de Enfermagem, Universidade de São Paulo; 2017.

\section{RESUMO}

Introdução: A necessidade de se avaliar a qualidade dos serviços de saúde oferecidos à população, além de constituir-se como consequência do princípio constitucional de eficiência da administração pública, compõe as diretrizes de diversas políticas públicas, razão pela qual este estudo se dirigiu à realização de uma pesquisa avaliativa em um serviço especializado em álcool e outras drogas, com vistas a prover subsídios para o aperfeiçoamento do sistema de saúde. Objetivo: Avaliar a satisfação dos profissionais, usuários e familiares e a percepção de mudanças dos usuários e familiares de um serviço de atenção psicossocial em álcool e outras drogas. Método: Trata-se de um estudo transversal de abordagem qualitativa, que empregou o método da Avaliação de Quarta Geração adaptado por Wetzel. A coleta de dados ocorreu entre os meses de abril a junho de 2017, por meio da aplicação de entrevistas individuais, valendo-se do círculo hermenêutico-dialético e de entrevistas grupais. Concordaram livremente em participar do estudo oito profissionais, 10 usuários e seis familiares do serviço. O projeto foi devidamente aprovado pelos respectivos comitês de ética em pesquisa. Resultados: As construções do grupo de profissionais acerca da satisfação foram tematizadas em três núcleos: clínica, gestão e ensino. Os usuários e os familiares apresentaram construções a respeito da satisfação e da percepção de mudanças que foram tematizadas em um único núcleo: cuidado. Conclusões: Os fatores que convergiram para a promoção da satisfação dos profissionais envolveram alguns aspectos e características da prática assistencial empreendida no serviço. Por outro lado, fatores relacionados à própria prática assistencial, além de outros atinentes à gestão do serviço e à educação permanente, conjugaram-se de modo a desfavorecer a satisfação dos profissionais. Os usuários manifestaram satisfação com o atendimento oferecido pelo serviço, destacando a qualidade do acolhimento. A respeito da percepção de mudanças, os usuários reconheceram que perceberam mudanças positivas em suas vidas como resultado do tratamento recebido no serviço. Acerca da avaliação da satisfação e da percepção de mudança dos familiares, houve consenso em relação à satisfação - considerada positiva, e dissenso em face da percepção de mudanças observadas na vida dos pacientes.

Palavras-chave: Pesquisas sobre serviços de saúde. Transtornos relacionados ao uso de substâncias. Serviços comunitários de saúde mental. Satisfação pessoal. 
Soares, RH. Participatory evaluation in a psychosocial care service in alcohol and other drugs [thesis]. São Paulo: School of Nursing, University of São Paulo; 2017.

\begin{abstract}
Introduction: The necessity to evaluate the quality of health services offered to the population, besides constituting itself as a consequence of the constitutional principle of the efficiency on public administration, also composes the many public policy guidelines, reason for which this study has been directed towards the realization of an evaluative research in a service specialized in alcohol and other drugs, having in mind to provide subsidies for the improvement of the health system. Objective: Evaluate professionals' satisfaction, users and relatives as well as the perception of change from a psychosocial service focused in alcohol and other drugs. Methods: A cross-sectional qualitative study, having used the Fourth Generation Assessment method, adapted by Wetzel. Data collection took place between April and June 2017, through individual interviews, using the hermeneutic-dialectical circle and group interviews. Eight professionals, 10 users and six family members agreed at their own free will to participate in this study. The project was duly approved by the respective research ethics committees. Results: The constructions of the group of professionals regarding satisfaction were themed in 3 nuclei: clinic, management and teaching. The users and families presented constructions in respect to satisfaction and the perception of changed which were themed in a single nucleus: care.
\end{abstract} Conclusions: The factors that converged to incentivize the satisfaction of professionals involved some aspects and characteristics of the care practice undertaken in the service. On the other hand, factors related to the care practice itself, in addition to others related to the service management and lifelong education, were combined in a way that made the professionals' satisfaction less favorable. The users manifested satisfaction with the service offered, highlighting the reception's welcoming quality. Regarding perceived changes, users have recognized that they have realized positive changes in their lives as a result of the treatment received at the service. In respect to the satisfaction evaluation and perception of change by the relatives, there was a consensus in relation to the satisfaction - considered positive, and dissent in face of the perception of changes observed in the life of the patients.

Keywords: Health services research. Substance-related disorders. Community mental health services. Personal satisfaction. 


\section{LISTA DE FIGURA}

Figura 1 - Círculo Hermenêutico-dialético 


\section{LISTA DE TABELAS}

Tabela 1 - Medianas obtidas com os escores globais da SATIS-BR aplicada aos profissionais nos anos de 2013 a 2014, segundo 12 CAPSad do Município de São Paulo. 42

Tabela 2 - Medianas obtidas com escores globais da SATIS-BR e da EMP aplicadas aos usuários nos anos de 2013 a 2014, segundo 12 CAPSad do Município de São Paulo.

Tabela 3 - Medianas obtidas com escores globais da SATIS-BR e da EMP aplicadas aos nos anos de 2013 a 2014, segundo 12 CAPSad do Município de São Paulo.

Tabela 4 - Soma das medianas obtidas com os escores globais da EMP aplicada aos usuários e familiares nos anos de 2013 a 2014, segundo 12 CAPSad do Município de São Paulo.

Tabela 5 - Soma das medianas obtidas com os escores globais da SATIS-BR aplicada aos profissionais, usuários e familiares nos anos de 2013 a 2014, segundo 12 CAPSad do Município de São Paulo 


\section{LISTA DE SIGLAS}

AQG

AIDS

CAAE

CAPSad

CLT

CONAD

DSM-IV

EAFAAA

EMP

FIOCRUZ

GEAD

PNAD

PNASS

PNEPS

OMS

ONU

RAPS

SAS-SECONCI

SATIS-BR

SISNEP

SUS

UAA

UNODC

WHO
Avaliação de Quarta Geração

Acquired Immunodeficiency Syndrome

Certificado de Apresentação para Apreciação Ética

Centro de Atenção Psicossocial em Álcool e outras Drogas

Consolidação das Leis do Trabalho

Conselho Nacional Antidrogas

Diagnostic and Statistical Manual of Mental Disorders IV

Escala de Atitudes Frente ao Álcool, Alcoolismo e Alcoolista

Escala de Mudança Percebida

Fundação Oswaldo Cruz

Grupo de Estudos em Álcool e Drogas

Política Nacional sobre Drogas

Programa Nacional de Avaliação de Serviços de Saúde

Política Nacional de Educação Permanente em Saúde

Organização Mundial da Saúde

Organização das Nações Unidas

Rede de Atenção Psicossocial

Superintendência de Atenção à Saúde - Serviço Social da Construção

Escala de Satisfação

Sistema Nacional de Informação sobre Ética em Pesquisa Envolvendo Seres Humanos

Sistema Único de Saúde

Unidade de Acolhimento Adulto

United Nations Office on Drugs and Crime

World Health Organization 


\section{SUMÁRIO}

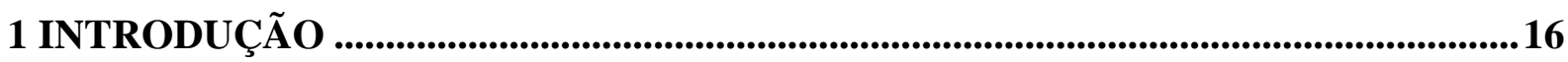

2 OBJETIVOS ..............................................................................................................22

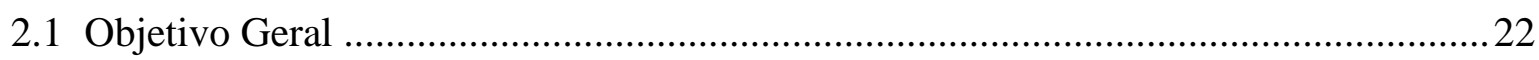

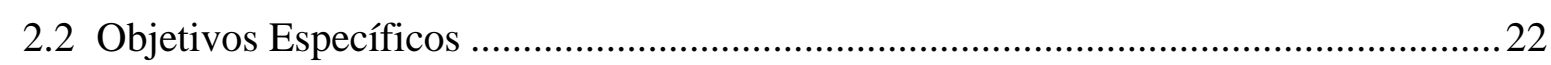

3 MÉTODO ................................................................................................................24

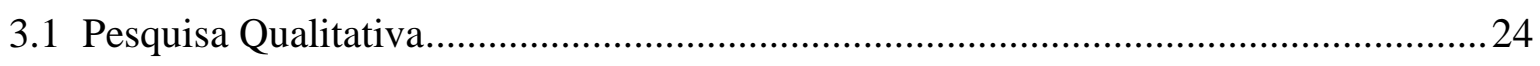

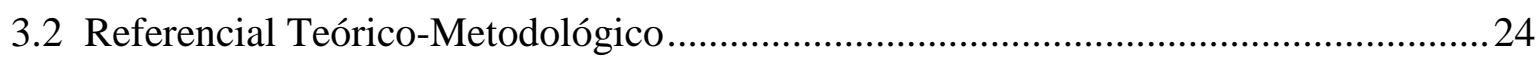

3.2.1 Avaliação de Quarta Geração de Guba e Lincoln ............................................. 24

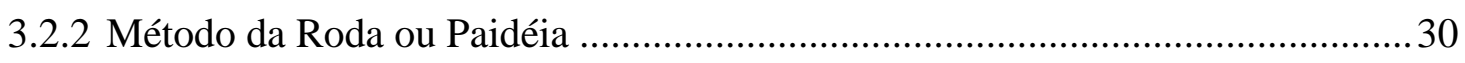

3.2.3 Modelo da Avaliação de Quarta Geração adaptado por Wetzel ......................... 32

3.2.4 Conceito de Satisfação ............................................................................. 35

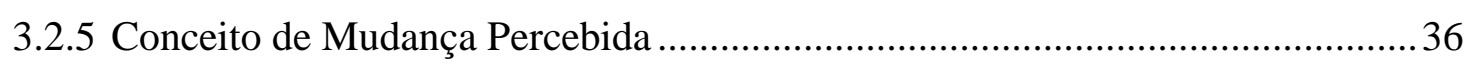

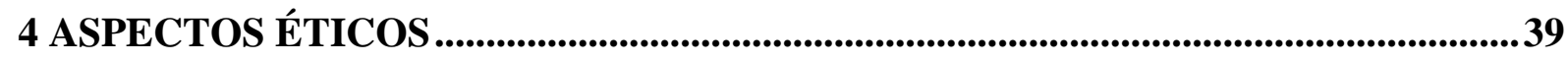

5 DESENVOLVIMENTO DO PROCESSO AVALIATIVO ........................................41

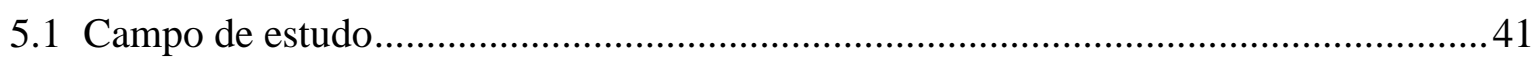

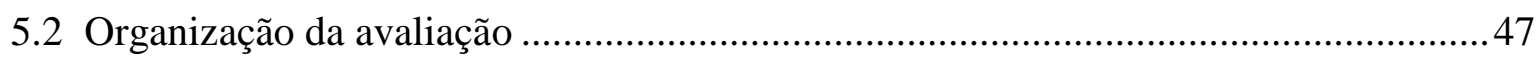

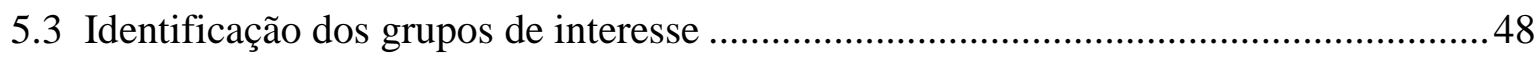

5.4 Desenvolvimento das construções conjuntas.......................................................... 48

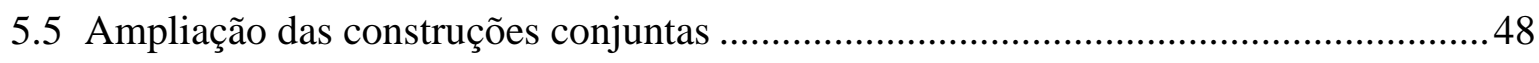

5.6 Preparação da apresentação das questões para os grupos de interesse .........................48

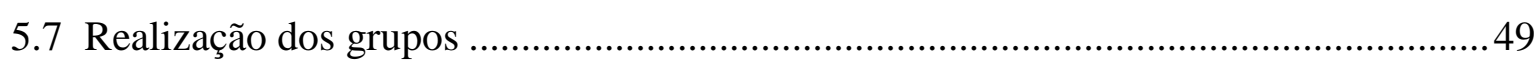

6 RESULTADOS E DISCUSSÃO .............................................................................51

6.1 Avaliação da satisfação dos profissionais .................................................................. 51

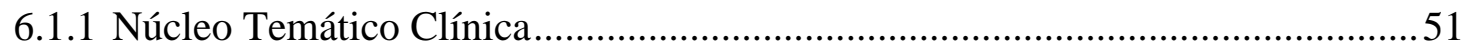

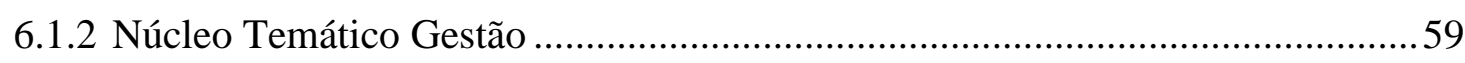

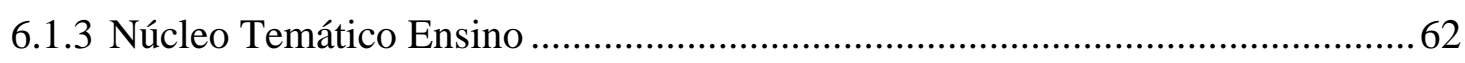

6.2 Avaliação da satisfação e da percepção de mudança dos usuários ............................... 64

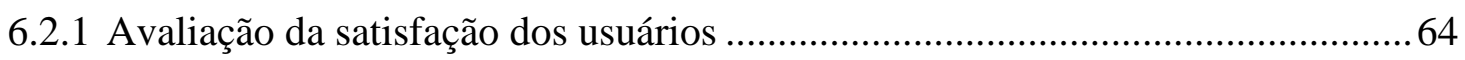

6.2.2 Avaliação da percepção de mudança dos usuários.......................................... 67 
6.3 Avaliação da satisfação e da percepção de mudança dos familiares 69

6.3.1 Avaliação da satisfação dos familiares.

6.3.2 Avaliação da percepção de mudança dos familiares

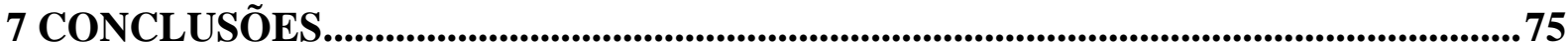

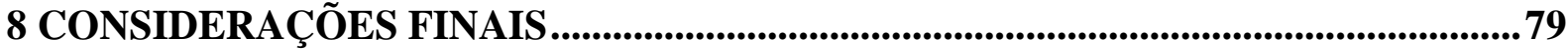

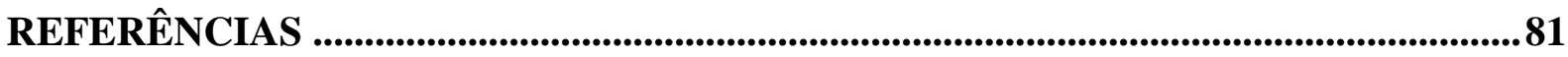

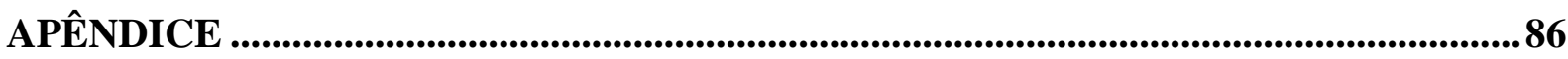

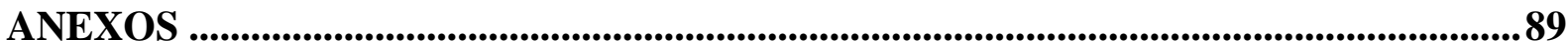


1 INTRODUCÃO 


\section{INTRODUÇÃO}

O consumo de álcool, tabaco e de outras drogas lícitas e ilícitas pela população mundial vem sendo objeto de pesquisas de órgãos subordinadas à Organização das Nações Unidas (ONU).

A Organização Mundial da Saúde (OMS), por meio de seu Relatório Global sobre Álcool e Saúde ${ }^{(1)}$, revelou que o uso nocivo de álcool constitui uma das principais causas mundiais de morbidade, incapacidade e mortalidade, com aproximadamente 3,3 milhões de óbitos por ano, o que representa 5,9\% de todas as mortes no mundo, estabelecendo percentual superior às taxas de mortalidade atribuídas à $\operatorname{AIDS}(2,8 \%)$, à tuberculose $(1,7 \%)$ e à violência $(0,9 \%)$

Com relação ao tabaco, a OMS estima que o seu uso engendre a morte de aproximadamente seis milhões de pessoas no mundo por ano, além de diminuir a expectativa e a qualidade de vida de seus usuários, pelo desenvolvimento de doenças como o câncer de pulmão e cardiopatias, que matam 36 milhões de pessoas a cada ano em todo o mundo. ${ }^{(2)}$

O Escritório das Nações Unidas sobre Drogas e Crime (UNODC) publicou em seu Relatório Mundial sobre Drogas ${ }^{(3)}$ a estimativa de que entre 3,5\% e 7\% da população mundial na faixa etária de 15 a 64 anos tinha feito uso de alguma droga ilícita ao menos uma vez no ano anterior ao da pesquisa. Além disso, houve a proliferação de novas substâncias psicoativas, que subiram de 251, em julho de 2009, para 348 em dezembro de 2013.

No Brasil, de acordo com dados do Segundo Levantamento Nacional de Álcool e Drogas $^{(4)}$, estima-se que metade da população faça uso de bebidas alcoólicas e que, desta proporção, $17 \%$ se enquadre, conforme o "Diagnostic and Statistical Manual of Mental Disorders IV" (DSM-IV), nos critérios de abuso e dependência de álcool. O mesmo estudo indicou, em relação ao tabaco, que a prevalência de brasileiros adultos fumantes é de 16,9\% e a prevalência de fumantes adolescentes (14 a 17 anos) é de 3,4\%.

No que se refere ao uso de drogas ilícitas, pesquisa realizada pela Fundação Oswaldo Cruz (FIOCRUZ) ${ }^{(5)}$ estimou que, nas 26 capitais brasileiras e no Distrito Federal, um milhão de pessoas faça uso regular de drogas ilegais (excluindo-se o uso de maconha) e que, deste universo, 370 mil pessoas (ou 35\%) sejam usuárias de crack e/ou similares (pasta base, merla e oxi)

A partir dos dados desses levantamentos global e doméstico sobre o consumo de álcool e de outras drogas lícitas e ilícitas, com efeito, a questão da demanda pública por assistência no 
âmbito da saúde ganha importância fundamental no sentido de legitimar a necessidade da oferta de programas, serviços e ações públicas atinentes à promoção, prevenção, assistência e reabilitação para a população-alvo.

As estratégias para a compreensão e abordagem das questões relativas ao uso prejudicial de álcool e de outras drogas no Brasil estão alinhadas às diretrizes do $\operatorname{UNODC}^{(3)}$, consistentes em investir no cuidado em saúde e nos direitos humanos de todos os usuários de drogas, em detrimento de medidas coercitivas de restrição de liberdade, seja na esfera jurídico-penal, seja no campo assistencial.

Esse alinhamento estratégico encontra respaldo jurídico no ordenamento brasileiro, primordialmente, pela instituição das leis $10.216 / 01^{(6)}$ e da Lei $11.343 / 06^{(7)}$. A primeira, também conhecida como Lei da Reforma Psiquiátrica, caracteriza-se, principalmente, por assegurar os direitos das pessoas com sofrimento mental e reorienta o modelo de assistência para serviços preferencialmente extra-hospitalares. Já a Lei 11.343/06, apesar de valer-se justiça retributiva na grande maioria dos seus dispositivos, introduziu o que se convencionou chamar de justiça restaurativa, especialmente em relação à conduta de porte de drogas para consumo próprio, no que retirou a possibilidade de aplicação de pena restritiva de liberdade para esses casos.

Além desses diplomas legais, as atuais políticas públicas instituídas no país para lidar especificamente com as questões relacionadas ao uso prejudicial de álcool e de outras drogas também consolidam essa compreensão no cuidado em saúde e nos direitos humanos: a Política Nacional sobre Drogas ${ }^{(8)}$, a Política Nacional sobre o Álcool ${ }^{(9)}$ e o Plano Integrado de Enfrentamento ao "crack" e outras drogas. ${ }^{(10)}$

A Política Nacional sobre Drogas (PNAD), em vigor desde outubro de 2005, estabelece os princípios norteadores para a redução da demanda e da oferta de drogas, salientando a necessidade de medidas de prevenção; de tratamento, recuperação e reinserção social; redução de danos sociais e à saúde; redução da oferta; estudos, pesquisas e avaliações. ${ }^{(8)}$

A Política Nacional sobre o Álcool, instituída em maio de 2007, estabelece fundamentos para o enfrentamento coletivo dos problemas relativos ao consumo de álcool por meio de ações intersetoriais e de estratégias para a redução de danos sociais à saúde e à vida, bem como em face de situações de violência associadas ao uso prejudicial de bebidas alcoólicas. ${ }^{(9)}$

O Plano Integrado de Enfrentamento ao crack e outras drogas, implementado em 2010, tem o escopo de promover a intersetorialidade, articulando e coordenando ações integradas de prevenção, tratamento e reinserção social de usuários, abusadores e dependentes de crack, álcool ou outras drogas. ${ }^{(10)}$ 
Observadas em conjunto, essas políticas públicas têm em comum a perspectiva de que a questão do uso prejudicial de álcool e de outras drogas é de natureza complexa e multifatorial e que suas ações estão direcionadas basicamente para o desenvolvimento de medidas assistenciais integradas de caráter reticular.

Como efeito dessas políticas e de suas bases legais, o Sistema Único de Saúde, regulamentado pela Lei 8.080/90 ${ }^{(11)}$, passou a contar, a partir de 2011, com a Rede de Atenção Psicossocial (RAPS), que oferece serviços e ações de atenção psicossocial para todas as pessoas com sofrimento mental, incluindo aqueles decorrentes do uso prejudicial de álcool e de outras drogas.

Composta por serviços de Atenção Básica (Estratégia de Saúde da Família, Núcleo de Apoio à Saúde da Família, Equipe de Consultório na Rua e Centro de Convivência e Cultura); de Atenção Psicossocial Estratégica (Centro de Atenção Psicossocial); de Atenção Residencial de Caráter Transitório (Unidades de Acolhimento, Serviços de Atenção em Regime Residencial, Comunidades Terapêuticas); de Atenção Hospitalar (Serviço de Atendimento Móvel de Urgência SAMU, Unidade de Pronto Atendimento e Serviço Hospitalar ou Enfermaria Especializada em Hospital Geral); de Estratégia de Desinstitucionalização (Serviço Residencial Terapêutico, Programa "de Volta pra Casa"); de Estratégia de Reabilitação Psicossocial (Empreendimentos de geração de trabalho e renda, Cooperativas Sociais), a RAPS segue, em grande parte de sua rede, excetuando-se os serviços de Comunidades Terapêuticas, os preceitos teórico-técnicos propostos pelo movimento de Reforma Psiquiátrica, que preconiza a adoção de tecnologias diversas das de caráter manicomial, propondo um modelo de assistência baseado em dispositivos de rede comunitária de atenção psicossocial e de "clínica ampliada" (termo ligado ao caráter não exclusivamente médico das práticas assistenciais em saúde mental), em detrimento do modelo psiquiátrico tradicional, centralizado no tratamento hospitalar.

Os Centros de Atenção Psicossocial em Álcool e Drogas (CAPSad), regulamentados em 2002 pelo Ministério da Saúde ${ }^{(12)}$, compreendem os dispositivos públicos de saúde especializados no atendimento de pessoas com sofrimento mental decorrente do uso prejudicial de álcool e de outras drogas.

Os CAPSad são responsáveis pela organização da rede de atenção a usuários de álcool e de outras drogas, regulando a porta de entrada da rede de assistência, bem como procedendo ao matriciamento das equipes de atenção básica e dos serviços e programas de saúde mental, na esfera de seu território. Estudo da FIOCRUZ ${ }^{(13)}$ sobre o perfil dos usuários de crack e/ou similares concluiu que: 
Em relação aos serviços para tratamento ambulatorial da dependência química, nos últimos 30 dias que antecederam à pesquisa, o CAPS-AD foi o mais acessado, ainda que por apenas $6,3 \%$ (IC95\%:4,9-8,0) desses usuários, reforçando assim a premente necessidade de ampliação e fortalecimento desses equipamentos no âmbito da rede de saúde, assim como as "pontes" (serviços intermediários, agentes de saúde, redes de pares, consultórios na rua) entre as cenas de uso e os serviços já instalados. (p. 27)

A relevância estratégica da oferta de serviços públicos de saúde destinados à prevenção, tratamento e reabilitação dos usuários, abusadores e dependentes de álcool e de outras drogas não se restringe apenas à questão da quantidade dessa oferta, mas também concerne à qualidade dos serviços que são oferecidos à população-alvo, de modo que, tão importante quanto disponibilizar os serviços assistenciais, é importante disponibilizá-los com qualidade.

O princípio constitucional da eficiência, incluído em 1998 por emenda à Constituição Federal $^{(14)}$, salienta a preocupação da administração pública pela melhoria da qualidade dos serviços públicos oferecidos à população, como resposta às críticas sobre a ineficiência dos serviços prestados pelo Estado.

A necessidade de se avaliar a qualidade dos serviços de saúde oferecidos à população, além de constituir-se como consequência do princípio constitucional de eficiência da administração pública, compõe as diretrizes de políticas públicas, como o Programa Nacional de Avaliação de Serviços de Saúde (PNASS) ${ }^{(15)}$ e, particularmente, com relação aos serviços de saúde mental em álcool e outras drogas, a Polícia Nacional sobre Drogas (PNAD) ${ }^{(8)}$.

O PNASS estabelece que a busca da melhoria da qualidade dos serviços de saúde tornou-se um imperativo técnico e social, exigindo a criação de normas e mecanismos de avaliação e de controle da qualidade das práticas assistenciais. O PNASS coloca os processos de avaliação como eixo fundamental do planejamento e da gestão do sistema de saúde, de modo a garantir ao público atendimento satisfatório com maior racionalidade no dispêndio dos recursos disponíveis. ${ }^{(15)}$

A PNAD, consolidada pela Secretaria Nacional de Políticas sobre Drogas (SENAD) vinculada ao Ministério da Justiça - propõe expressamente a necessidade de avaliação dos serviços de saúde mental decorrente do consumo prejudicial de drogas. ${ }^{(8)}$ 
da oferta, considerando que os resultados orientarão a continuidade ou a reformulação dessas práticas. (p. 23)

A realização de processos avaliativos nos serviços de saúde especializados no atendimento de pessoas com sofrimento mental, decorrente do uso prejudicial de álcool e de outras drogas, constitui-se como recurso hábil para a construção de diagnósticos, orientações e para o desenvolvimento de serviços e programas cientificamente fundamentados, com vistas a aprimorar os serviços disponíveis, provendo subsídios para o aperfeiçoamento do sistema de saúde e para a eventual tomada de decisão por parte dos gestores, no sentido de prosseguir ou reformular as práticas e programas incorporados. A avaliação de serviços públicos de saúde "é área de extrema relevância, já que viabiliza escolhas de planejamento e possibilita um controle técnico e social dos serviços e programas prestados à sociedade"(16).

Nesse sentido, este estudo empreendeu uma avaliação em um serviço de atenção psicossocial em álcool e outras drogas com a finalidade de aferir a satisfação dos profissionais engajados no serviço, bem como aferir a satisfação e a percepção de mudança dos usuários e familiares atendidos pelo referido equipamento de saúde.

A presente pesquisa compreendeu um dos eixos da pesquisa matricial desenvolvida pelo Grupo de Estudos em Álcool e Drogas (GEAD) do Programa de Pós-graduação da Escola de Enfermagem da Universidade de São Paulo, intitulada “Avaliação global das necessidades individuais de usuários e dos serviços de álcool e outras drogas", que tem realizado pesquisas avaliativas de natureza quantitativa nos CAPSad de alguns Estados da federação ${ }^{(17-20)}$.

Com efeito, este estudo empregou a abordagem qualitativa de pesquisa no intuito de produzir conhecimentos complementares (qualitativos) aos trazidos pelas pesquisas quantitativas.

Intencionalmente, foi eleito como campo para a pesquisa o serviço de atenção psicossocial em álcool e outras drogas, que recebeu os escores mais baixos nos instrumentos aplicados aos CAPSad do município de São Paulo, cujas informações se encontram armazenadas no banco de dados do GEAD na esteira da mencionada pesquisa matricial. 
2 OBJETIVOS 


\section{OBJETIVOS}

\subsection{Objetivo Geral}

Avaliar qualitativamente a satisfação dos profissionais, usuários e familiares e a mudança percebida pelos usuários e familiares do CAPSad que recebeu os escores mais baixos nos instrumentos de mensuração da satisfação e da mudança percebida aplicados aos CAPSad do município de São Paulo, cujos dados se encontram armazenados no banco de dados do GEAD.

\subsection{Objetivos Específicos}

- Identificar o CAPSad que recebeu os escores mais baixos nos instrumentos de mensuração da satisfação e da mudança percebida aplicados aos CAPSad do município de São Paulo, cujos dados se encontram armazenados no banco de dados do GEAD;

- Avaliar qualitativamente a satisfação dos profissionais, usuários e familiares do CAPSad;

- Avaliar qualitativamente a mudança percebida pelos usuários e familiares com o serviço oferecido pelo CAPSad. 
3 MÉTODO 


\section{MÉTODO}

\subsection{Pesquisa Qualitativa}

Em consonância com os objetivos estabelecidos, adotou-se a abordagem qualitativa de pesquisa, que se caracteriza pelo estudo de questões particulares, em um patamar de realidade que não pode ou não deveria ser quantificado, qual seja, o universo dos significados, dos motivos, das aspirações, das crenças, dos valores e das atitudes ${ }^{(21)}$.

A pesquisa de natureza qualitativa trabalha com a intensidade dos fenômenos, ou seja, trata dos aspectos (significados) que a tornam específica e singular. As pesquisas qualitativas preocupam-se com a dimensão sociocultural, com as crenças, os valores, as opiniões, as representações, as formas de relação, as simbologias, os usos, os costumes, os comportamentos e as práticas ${ }^{(22)}$.

\subsection{Referencial Teórico-Metodológico}

Em relação ao referencial teórico-metodológico, a presente pesquisa valeu-se do modelo da Avaliação de Quarta Geração adaptado por Wetzel ${ }^{(23)}$.

Esse modelo, basicamente, conjuga referenciais metodológicos da Avaliação de Quarta Geração (AQG), proposta por Guba e Lincoln ${ }^{(24)}$, e do método da Roda ou Paidéia, concebido por Campos ${ }^{(25)}$.

\subsubsection{Avaliação de Quarta Geração de Guba e Lincoln}

O método de avaliação de programas e serviços proposto por Guba e Lincoln ${ }^{(24)}$, denominado de Avaliação de Quarta Geração (AQG), propõe-se a transpor os métodos tradicionais de avaliação, consistentes na mensuração, na descrição e no julgamento, acrescentando-lhes a dinâmica da negociação.

Para os autores da AQG, a avaliação de programas e serviços é resultado de um processo de evolução, de construção e de reconstrução sucessiva. Na primeira geração, explicam os autores, a avaliação centraliza-se na mensuração e é particularmente usada na avaliação dos sistemas escolares e nos processos produção. Essa espécie de avaliação confere ao avaliador a função técnica de mensurar qualquer variável a partir do emprego de determinados instrumentos elaborados para esta finalidade. 
A segunda geração da avaliação é denominada pelos autores como descritiva e caracteriza-se pela descrição de padrões (pontos fortes e fracos) em relação a determinados objetivos. A função do avaliador nesse processo é da ordem de um descritor, apesar de manter a característica técnica da mensuração, presente na avaliação de primeira geração.

Os autores tratam a avaliação que agrega o juízo de valor ao processo avaliativo como terceira geração. Nessa proposta, o avaliador assume a função de julgador, retendo ainda as funções técnicas e descritivas, típicas das gerações de avaliação anteriores.

A gradação ascendente, em gerações, é realizada pelos autores como demonstração da evolução dos processos de avaliação, representando avanço nos métodos avaliativos, de modo que a denominada quarta geração configura-se como passo adiante nos sistemas avaliativos, especialmente em razão da incorporação da dinâmica da negociação.

Entretanto, a peculiaridade do expediente da negociação nos processos avaliativos demandou a adoção dos métodos construtivista e responsivo, em contraste com os processos avaliativos anteriores, porquanto baseados no paradigma positivista.

Diferentemente das gerações de avaliação anteriores, baseadas no positivismo científico, a AQG fundamenta-se em dois elementos metodológicos, quais sejam, um enfoque responsivo e uma metodologia construtivista.

O enfoque responsivo representa a antítese das avaliações tradicionais, cujos temas são definidos previamente pelos avaliadores e clientes. $\mathrm{O}$ enfoque responsivo concede o direito aos interessados na avaliação de apresentarem (responderem) suas reivindicações, preocupações e questões sem que elas tenham sido previamente formuladas pelos avaliadores e clientes.

A metodologia construtivista da AQG parte do pressuposto de que a realidade é uma construção produzida pelas pessoas, que sofrem influências de natureza social e cultural. $\mathrm{O}$ método construtivista opõe-se ao paradigma positivista, em relação ao qual a realidade é objetiva e independente do observador.

O enfoque responsivo e o aporte da metodologia construtivista conferem à AQG cinco características principais, que a diferenciam das avaliações tradicionais.

Em primeiro lugar, seus resultados não são descrições das coisas, mas construções elaboradas por pessoas ou grupos específicos que lhes atribuem determinado sentido. Em outras palavras, os resultados da avaliação não podem ser entendidos como fatos, mas como produções criadas por meio de processos interpessoais.

Em segundo lugar, ainda com relação às construções, a AQG as reconhece como formulações providas de pluralidade de valores próprios de seus construtores, ou seja, a AQG 
leva em conta os diversos valores e os diferentes contextos das pessoas e grupos implicados no processo avaliativo.

Como terceira característica, os resultados da AQG estão adstritos a um contexto específico, em relação ao qual as pessoas e os grupos implicados atribuem sentido. Essa perspectiva de especificação do contexto vivido por eles possibilita a realização de consensos, uma vez que os envolvidos pertencem à mesma realidade objeto de avaliação.

Uma quarta característica própria da AQG é a de que ela pressupõe a outorga de poder e a concessão de direitos entre as pessoas e grupos implicados na avaliação, ou seja, a AQG pressupõe igualdade e equilíbrio de direitos entre os interessados na avaliação, também chamados de "stakeholders".

Como quinta característica, a AQG preconiza que o resultado da avaliação deve servir a todos os implicados, mediante sua efetiva participação na etapa de negociação. Com efeito, a AQG apregoa a necessidade de haver paridade de direitos entre os interessados a fim de garantir a efetiva participação de todos na emergência das construções compartilhadas.

Com relação à operacionalização, a AQG estabelece um processo baseado em até 12 etapas, que podem ser realizadas em sua totalidade ou não, dependendo da proposta de avaliação e/ou dos próprios resultados encontrados durante seu processamento.

As 12 etapas operacionais da AQG compreendem: 1) formalização do contrato com o cliente; 2) organização logística da avaliação; 3) identificação dos grupos de interesse; 4) produção das construções compartilhadas pelos grupos de interesse; 5) ampliação das construções dos grupos de interesse; 6) seleção das reivindicações, preocupações e questões resolvidas; 7) priorização das reivindicações, preocupações e questões ainda não resolvidas; 8) seleção de informações relacionadas às reivindicações, preocupações e questões não resolvidas; 9) preparação da agenda de negociação; 10) condução da negociação; 11) divulgação dos resultados; 12) reciclagem.

A primeira etapa da AQG consiste na formalização do contrato com o cliente. Os autores do método aconselham que seja elaborado um contrato formal, no qual devem constar as seguintes questões: identidade do cliente (patrocinador da avaliação) e do sujeito ou entidade a ser avaliada; especificação dos propósitos da avaliação; declarações recíprocas das partes comprometendo-se a respeitar as condições para a realização do processo hermenêuticodialético; declaração do avaliador acerca do compromisso de manutenção do anonimato dos participantes envolvidos e da confidencialidade dos dados obtidos; descrição do formato de divulgação dos resultados, preferencialmente por meio de relato de caso; e, ainda, a descrição de determinadas particularidades técnicas, como o orçamento, informações a respeito da 
formação e experiência dos avaliadores e dados acerca dos possíveis resultados que podem ser esperados da AQG.

A organização logística da avaliação compreende a segunda etapa do processo da AQG. É uma fase de preparação da avaliação, na qual o avaliador realiza a seleção e o treinamento da equipe que atuará no campo de avaliação. É nessa mesma etapa que o avaliador busca obter acesso aos participantes da avaliação, almejando constituir com eles relação de confiança, baseada no respeito e integridade mútuos.

A terceira etapa do processo da AQG consiste na identificação dos grupos de interesse, também chamados de grupos de implicados ou de "stakeholders". A identificação desses grupos é primordial na AQG, porquanto que cada qual é titular legítimo de determinados interesses que serão expostos a riscos no processo de avaliação, motivo pelo qual cada grupo de interesse deve ser reconhecido como tal e convidado a participar da avaliação.

A elaboração de construções conjuntas dentro do grupo de interesse corresponde à quarta etapa da AQG. Nessa fase, realiza-se o Círculo Hermenêutico-dialético (CHD) com cada um dos grupos de interesse identificados na etapa anterior.

O CHD opera-se da seguinte maneira: o primeiro participante do círculo é convidado a contribuir para a avaliação, apresentando suas reivindicações, preocupações e questões, gerando, portanto, uma primeira construção. Essa construção inicial é submetida à análise pelo avaliador, que identifica os desdobramentos do conteúdo da entrevista. Esses desdobramentos identificados na construção inicial são apresentados ao próximo participante do círculo para a obtenção de comentários e críticas, ensejando, ao final da entrevista, uma nova construção (reconstrução), que, a seu turno, será objeto de nova análise, visando a exposição de seus desdobramentos ao o terceiro respondente, e assim por diante, seguindo-se esse processo até o último respondente, conforme o esquema representado pela figura 1.

A proposta do CHD é possibilitar que o processo de construção das reivindicações, preocupações e questões dos interessados seja participativo, incluindo as contribuições de todos os respondentes com a finalidade de gerar construções conjuntas. Guba e Lincoln esclarecem que, apesar do CHD objetivar a construção de consensos, não há garantias de que todas construções emergentes dos círculos serão compartilhadas pelos seus participantes. 
Figura 1 - Círculo Hermenêutico-dialético

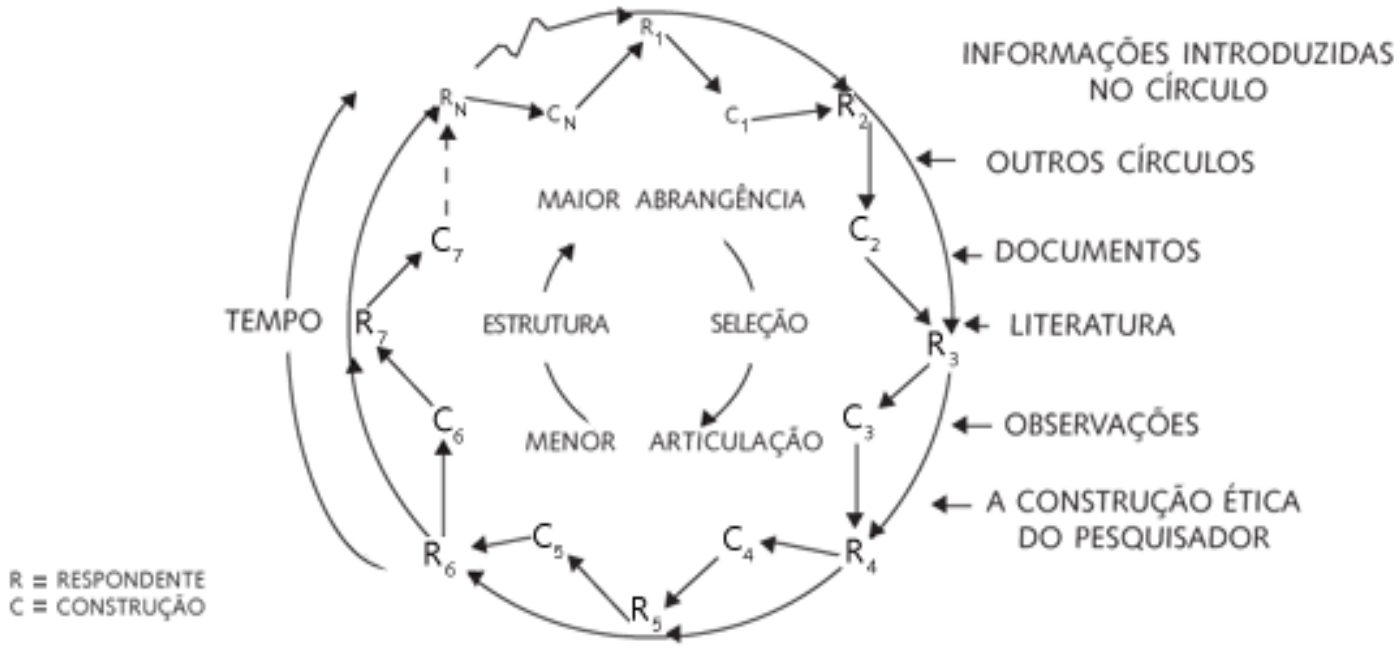

Fonte: Guba e Lincoln (2011:169) 24$)$

A quinta etapa da AQG é dedicada à ampliação das construções conjuntas dos grupos de interesse, com a introdução de informações que possibilitem mais esclarecimento aos grupos de implicados, principalmente em relação às reivindicações, preocupações e questões divergentes, com o escopo de alcançar o consenso. Segundo os autores, as informações a serem fornecidas aos "stakeholders" podem ser compiladas de fontes diversas: documentos e registros, observação, publicações profissionais, outros círculos de interessados, a partir da construção ética do avaliador.

A sexta fase da AQG envolve a seleção das reivindicações, preocupações e questões resolvidas. Para Guba e Lincoln, são consideradas "resolvidas" as reivindicações, preocupações e questões que foram objeto de consenso do grupo de interessados. Nessa fase, as demandas resolvidas são selecionadas e reservadas para o momento da elaboração da análise final da avaliação.

Havendo as não resolvidas, ou seja, que não foram objeto de consenso entre os participantes do CHD, passa-se para a próxima etapa da AQG, salientando que o avaliador finalizaria o processo na etapa anterior se, eventualmente, as reivindicações, preocupações e questões do grupo de interessados tivessem alcançado total consenso.

Com efeito, a sétima etapa tem o escopo de priorizar as reivindicações, preocupações e questões não resolvidas, classificando-as em ordem de prioridade na perspectiva do grupo de interessados. A realização dessa classificação é importante para o processo avaliativo em razão 
da possibilidade de se trabalhar com um grande número de demandas não resolvidas. $\mathrm{Na}$ classificação, deve-se considerar o nível de dificuldade de resolução das reivindicações, preocupações e questões, priorizando-se aquelas com mais facilidade de solução, a probabilidade da obtenção de um compromisso entre os interessados acerca de um plano de ação e a centralização no conjunto de valores dos interessados, que fundamentam suas reivindicações, preocupações e questões.

A oitava etapa do processo da AQG reserva-se à compilação de informações para o alcance de um nível mais alto de esclarecimento dos grupos implicados acerca das reivindicações, preocupações e questões não resolvidas. As informações a serem coletadas podem ser extraídas dos CHD realizados com outros grupos de interesse, bem como de publicações profissionais, como descrito na quinta etapa.

A preparação da agenda de negociação, nona fase da AQG, requer a adoção de diversas providências por parte do avaliador, quais sejam, definição das reivindicações, preocupações e questões correspondentes ao grupo ou aos grupos de interesse; salientar os elementos de controvérsia das reivindicações, preocupações e questões, responsáveis pelo dissenso entre os interessados; disponibilizar informações que favoreçam o esclarecimento dos interessados a respeito das divergências existentes; proporcionar treinamentos, realizar dinâmicas de representação de papéis e oferecer oportunidades para aumentar o nível de esclarecimento dos "stakeholders"; testar a agenda, aplicando-a a representantes dos interessados com o fim de verificar sua pertinência e adequação.

A décima etapa do processo da $\mathrm{AQG}$ corresponde à condução da negociação. Os autores sugerem que a negociação seja conduzida, preferencialmente, por meio do CHD. A etapa de negociação deve prosseguir até que se estabeleça o menor número de construções conflitantes possível, em virtude da dificuldade de se alcançar o consenso total. Ainda conforme os autores, as negociações são encerradas de modo relativamente arbitrário, seja por esgotamento dos recursos ou do tempo conferidos para a realização da avaliação.

Concluída a negociação, a AQG segue para a sua décima primeira etapa, consistente na divulgação dos resultados, com a apresentação do relatório da avaliação.

Os autores propõem, ainda, uma última etapa (décima segunda), chamada de reciclagem, que consiste em proceder a uma reavaliação, considerando a probabilidade de que os participantes do primeiro processo avaliativo ampliem ainda mais seu nível de esclarecimento acerca das reivindicações, preocupações e questões que emergiram durante o processo anterior, abrindo espaço para novas reconstruções compartilhadas, em um segundo momento avaliativo. 


\subsubsection{Método da Roda ou Paidéia}

O método da Roda, também chamado de método Paidéia, foi desenvolvido pelo Professor Gastão Wagner de Sousa Campos, em sua tese de livre-docência intitulada "Um método para análise e cogestão de coletivos", que deu origem ao livro de mesmo título, publicado em $2005^{(25)}$

O método da Roda ou Paidéia está centrado em três conceitos fundamentais: valor de uso, constituição do sujeito e democracia nas organizações, a partir dos quais o autor trabalha com a hipótese de que durante os processos de produção de bens e serviços com valor de uso ocorre simultaneamente a coprodução de sujeitos e de coletivos $^{(26)}$.

Essa coprodução de valores de uso, de subjetividades e de coletivos ocorrendo concomitantemente constitui a premissa teórica para a proposta do método Paidéia, consistente em trabalhar não somente com a produção de coisas, mas também trabalhar a constituição de pessoas e de coletivos organizados ${ }^{(25,26)}$.

Nesse sentido, o autor desenvolve a noção de fator Paidéia, que corresponderia à propriedade que os processos de gestão têm de modular a constituição dos sujeitos no caminho de seu desenvolvimento integral. A própria denominação "Paidéia" tem esse sentido, porquanto trata-se de um antigo conceito clássico grego, significando desenvolvimento integral do ser humano $^{(25,26)}$.

Já a designação do método como "Roda" está associado aos espaços coletivos, tidos como próprios para o exercício da reflexão crítica e da produção de subjetividades, além de constituir-se como espaços de participação democrática. Conforme o autor, o termo "Roda" foi inspirado nas rodas realizadas pelos pedagogos construtivistas, nas rodas de samba, nas rodas do candomblé e nas rodas de ciranda. A Roda, portando, é entendida como um espaço democrático para o exercício da cogestão de pessoas e de coletivos organizados ${ }^{(25,26)}$.

O método da Roda ou Paidéia tem como objetivo aumentar a capacidade de análise e de intervenção das pessoas e dos coletivos organizados, ou seja, tem a finalidade de que as pessoas e os coletivos organizados aprimorem o conhecimento que detêm sobre seus próprios problemas e passem a agir efetivamente sobre eles na busca de soluções ${ }^{(25,26)}$.

A ocorrência do incremento da capacidade de análise e de intervenção das pessoas e dos coletivos organizados depende da transformação das gestões administrativas, baseadas na racionalidade gerencial hegemônica, para a cogestão (participativa) de pessoas e de coletivos $\operatorname{organizados}^{(25)}$. 
Segundo o autor, a racionalidade gerencial hegemônica, fundada por Taylor, produz sistemas de direção que se baseiam no aprisionamento das vontades e na retirada do poder de governo da maioria. O modelo da racionalidade gerencial dominante, além de comprar a força de trabalho das pessoas, determina que elas renunciem a seus desejos e interesses e os substitua por objetivos, normas e pelo salário ${ }^{(25)}$.

O método Paidéia propõe, ao contrário do preconizado pela racionalidade gerencial dominante, que os desejos e interesses dos trabalhadores estejam integrados ao processo de produção. A incorporação dos desejos e interesses dos trabalhadores nos processos de trabalho prioriza a satisfação e a realização pessoal dos trabalhadores, configurando-se em um espaço de manifestação dos desejos e interesses dos trabalhadores. O método da Roda avalia que somente com a síntese entre os desejos e interesses dos trabalhadores e o processo produtivo é que se pode realizar "obras", no sentido de possibilitar aos trabalhadores a satisfação e realização pessoal ${ }^{(25)}$.

O sistema de produção baseado no taylorismo (racionalidade gerencial dominante) produz subjetividades diversas, conforme se trate de dirigentes ou de trabalhadores, esperandose dos primeiros iniciativa, audácia, criatividade e habilidade no comando; enquanto que dos trabalhadores, espera-se ordem, habilidade e obediência ${ }^{(25)}$.

Essa produção de subjetividades diversas enseja a ocorrência dos processos de alienação, que se expressam na diminuição da autonomia dos trabalhadores e na impossibilidade de participação na gestão ${ }^{(25)}$.

Em contraste com o modelo da racionalidade gerencial hegemônica (anti-Paidéia), o método da Roda propõe a criação de espaços coletivos como meio para diminuir a alienação dos trabalhadores e, consequentemente, aumentar sua capacidade de análise e de intervenção. Por meio dos espaços coletivos, para o método Paidéia, as pessoas podem interferir nos processos de produção e realizar a cogestão das instituições de forma participativa e democrática $^{(25)}$.

A gestão democrática e participativa, que se expressa por meio da construção de processos de cogestão, corresponde ao eixo de conformação do método anti-Taylor ou do método da Roda ${ }^{(25)}$. 


\subsubsection{Modelo da Avaliação de Quarta Geração adaptado por Wetzel}

O modelo da AQG adaptado por Wetzel ${ }^{(23)}$ é resultado da construção de um método de avaliação participativa de serviços de saúde que aproxima a AQG de Guba e $\operatorname{Lincoln}^{(24)}$ do método da Roda ou Paidéia de Campos ${ }^{(25)}$.

A proposta de aproximação da AQG (Guba e Lincoln) com o método Paidéia (Campos), defendida por Wetzel, também é sustentada por Furtado ${ }^{(27)}$, para quem essa aproximação de métodos é tida como potencialmente mais adequada para a avaliação de serviços e programas, principalmente a partir das questões decorrentes dos processos de desinstitucionalização em saúde e das próprias limitações das avaliações ortodoxas.

Furtado aponta que o alinhamento entre esses dois métodos está baseado no referencial participativo e construtivista comum a ambos. Argumenta, ainda, que os autores da AGQ e do método da Roda parecem concordar com o fato de que a dificuldade dos grupos de analisar sua própria realidade está mais ligada a entraves de natureza política, organizacional e subjetiva, que prejudicam as trocas e o restabelecimento de novos modos de organização ${ }^{(27)}$.

\subsubsection{Etapas do processo avaliativo}

Wetzel propõe sete etapas para operacionalização do processo de avaliação participativa de um serviço, quais sejam, contato com o campo; organização da avaliação; identificação dos grupos de interesse; desenvolvimento das construções conjuntas; ampliação das construções conjuntas; preparação da apresentação das questões para os grupos de interesse; e realização dos $\operatorname{grupos}^{(23)}$.

O contato com o campo corresponde ao momento da apresentação formal do projeto de pesquisa avaliativa aos gestores do serviço de saúde designado para a avaliação, bem como para aos respectivos comitês de ética em pesquisa.

A etapa de organização da avaliação envolve a conquista do "direito de entrada" por parte do avaliador no campo. $\mathrm{O}$ "direito de entrada" consiste na construção de uma relação de confiança entre o avaliador e os interessados na avaliação. Nessa etapa, também é esperado que o avaliador adquira vivências e experiências no contexto dos interessados, de maneira que empreenda a "etnografia prévia" no serviço para conhecer os interessados e também ser conhecido por eles. 
A identificação dos grupos de interesse, também chamados de grupos de implicados ou de "stakeholders", acontece a partir da vivência do avaliador no campo, própria da etapa anterior (etnografia prévia).

Identificados os grupos de interesse, segue-se para a fase de desenvolvimento das construções conjuntas, que corresponde à aplicação do CHD, realizando-se um círculo para cada grupo de interesses previamente identificado.

A ampliação das construções conjuntas ocorre no momento da aplicação do CHD, quando o avaliador introduz informações para aumentar o nível de esclarecimento dos respondentes. As informações podem ser originárias das observações do avaliador no campo, da literatura profissional e da construção ética do avaliador.

A etapa de preparação da apresentação das questões para os grupos de interesse envolve a logística para a realização dos grupos. $\mathrm{Na}$ preparação, o avaliador deve convidar os participantes de cada círculo para a realização dos mesmos, bem como preparar a forma como apresentará os resultados (provisórios) da análise dos dados.

A realização dos grupos constitui-se como a última etapa operacional do processo avaliativo, tratando-se do momento da devolutiva dos resultados provisórios aos respectivos grupos de interesse, com vistas à obtenção da validação das construções conjuntas. Nesse momento, também é realizada a negociação das construções conflitantes entre os participantes de cada grupo, objetivando o consenso.

\subsubsection{Técnicas de coleta de dados}

Os dados empíricos primários do presente estudo foram coletados em campo mediante a aplicação das técnicas de entrevista e de observação.

Guba e Lincoln apregoam que a principal tarefa do pesquisador é fazer florescer as construções que os diferentes atores mantêm em um determinado ambiente/circunstâncias e fazer com que elas se associem $^{(24)}$.

Nesse sentido, as entrevistas foram conduzidas pelo processo do círculo hermenêuticodialético (CHD), no qual o primeiro entrevistado é convidado a responder a uma ou mais questões abertas. Após cada entrevista, o pesquisador-entrevistador realiza análise da fala buscando a identificação de elementos relevantes acerca do tópico investigado para ser apreciado pelo próximo entrevistado. Dessa maneira, a partir do segundo participante, todos os outros são convidados a responder às questões inicias e a opinar sobre os elementos que 
surgirem ao longo das análises das entrevistas de cada sujeito do estudo em seus respectivos grupos de interesse.

A técnica de observação - ou observação participante - possibilita contato pessoal e próximo do pesquisador com o objeto de estudo, o que representa a vantagem de verificar a ocorrência do fenômeno, permitir ao observador aproximação com a perspectiva dos sujeitos e descobrir novos aspectos relacionados ao problema ${ }^{(28)}$.

Os dados da observação, conforme Guba e Lincoln, podem tomar formas diversas nos diversos momentos da pesquisa. Em um primeiro momento, a observação pode ser pouco estruturada, permitindo ao observador expandir seu conhecimento e desenvolver senso acerca do que é importante. Em um segundo momento, o observador pode concentrar seu foco e aprofundar aspectos relevantes à investigação ${ }^{(24)}$.

\subsubsection{Técnica de análise de dados}

A proposta de avaliação participativa determina que a análise e a coleta de dados sigam processos paralelos, um orientando o outro. Essa dinâmica entre os processos de coleta e de análise de dados é realizada mediante o emprego do método comparativo constante ${ }^{(23)}$.

O método comparativo constante deve ocorrer para garantir a efetiva participação dos interessados no processo avaliativo, uma vez que, nas avaliações participativas, os interessados são convidados a interferir em ambos os processos (coleta e análise de dados) para assegurar que os resultados empíricos sejam validados pelos próprios interessados.

A técnica de comparação constante é administrada da seguinte maneira: após a realização de uma entrevista, a primeira providência do avaliador é realizar imediatamente análise do conteúdo dessa entrevista com vistas a identificar as unidades de informação nela contidas. Estas caracterizam-se por serem heurísticas - apontam para algum entendimento ou ação do avaliador - e por serem a menor parte de informação acerca de algo que se mantem por si. Na posse das unidades de informação compiladas na entrevista, o avaliador deve apresentálas ao próximo entrevistado, o qual será convidado a apreciá-las e a tecer comentários a seu respeito. Essa análise realizada imediatamente após cada entrevista tem o objetivo de apresentar os desdobramentos da entrevista anterior para o próximo respondente, ou seja, os dados analisados nas entrevistas precedentes são apresentados nas entrevistas subsequentes ${ }^{(23,24)}$.

Finalizadas as entrevistas individuais do CHD, as unidades de informação compiladas são, então, categorizadas em núcleos temáticos para sua validação e negociação pelos grupos de interessados. A categorização dos núcleos temáticos consiste no agrupamento de unidades 
de informação que guardam relações entre si. Cada núcleo corresponde a um tema que foi objeto de reflexão por parte dos grupos de interesse ${ }^{(23)}$.

\subsubsection{Conceito de Satisfação}

O conceito de satisfação, de acordo com o dicionário ${ }^{(29)}$, compreende os seguintes significados: 1) ato ou efeito de satisfazer (-se), contentamento; 2) contentamento, alegria, deleite, aprazimento; 3) pagamento, recompensa, retribuição; 4) indenização, reparação, expiação; e 5) explicação, justificativa, justificação.

Esperidião e $\operatorname{Trad}^{(30)}$ partem do pressuposto de que o conceito de satisfação é polissêmico. Essa polissemia conceitual da satisfação foi objeto de estudo dos referidos autores, que ao realizarem análise do conceito de satisfação empregado nas pesquisas de avaliação de serviços de saúde, verificaram que a grande maioria dos estudos pesquisados não apresentou modelo teórico de razoável consistência em função da complexidade conceitual da satisfação.

Em conformidade com o aporte teórico-metodológico adotado na presente pesquisa, o conceito de satisfação, que subsidiou a análise e discussão dos dados empíricos, seguiu o referencial teórico do método da Roda ou Paidéia ${ }^{(25)}$.

O conceito de satisfação dos trabalhadores para o Método da Roda está ligado à ideia de realização pessoal. Essa realização pessoal é entendida como a possibilidade de os trabalhadores integrarem seus desejos e interesses durante todo o curso do processo laborativo $^{(25)}$.

A inclusão deliberada dos desejos e interesses dos trabalhadores no processo de trabalho visando a realização pessoal diverge da posição teórica adotada pela racionalidade gerencial dominante, que preconiza a concentração dos desejos e interesses dos trabalhadores exclusivamente no recebimento do salário, ensejando, portanto, certa renúncia, por parte dos trabalhadores, à dimensão criativa do trabalho, substituindo liberdade e realização pessoal por dinheiro $^{(25)}$.

Essa cisão entre trabalho e prazer pode ser observada na asserção de Henry Ford: "Quando trabalhamos, precisamos trabalhar; quando nos divertimos, devemos nos divertir. O que não se pode é conduzir as duas coisas. O único objetivo deve ser entregar o trabalho feito e receber uma paga." (p. 132)

Em contraste com o discurso da racionalidade gerencial dominante, consistente na ideação de que os desejos e interesses dos trabalhadores devam se concentrar no pagamento do salário, o Método da Roda postula que o trabalho não se limitaria ao escopo de garantir a 
sobrevivência dos trabalhadores por meio de uma remuneração, mas também teria o potencial de lhes proporcionar realização pessoal, consubstanciando-se em um espaço de manifestação de seus desejos e interesses ${ }^{(25)}$.

O Método da Roda se vale da noção de obra como possibilidade de sintetizar a realização pessoal dos trabalhadores. A obra, nas palavras do autor, "funciona como uma ponte" entre os desejos e interesses dos trabalhadores e o processo de produção, representando tanto "o resultado do trabalho, quanto a própria invenção de jeitos particulares para organizar o processo de trabalho. Gozar com o resultado e com o processo. Realizar-se durante o caminho e quando da chegada." (p. 135)

A noção de obra, portanto, depende da ampliação da compreensão de resultados do trabalho. Os resultados do trabalho não se restringiriam ao resultado final (o produto ou serviço), mas abrangeriam também os efeitos gerados no curso do processo de trabalho, desde a concepção do projeto até a execução, de modo que os trabalhadores tenham a oportunidade de participar do processo de construção das diretrizes, dos objetivos, do objeto e dos métodos de trabalho, possibilitando, então, a realização de obras coletivas ${ }^{(25)}$.

\subsubsection{Conceito de Mudança Percebida}

Os processos de avaliação de serviços de saúde têm se valido dos relatos dos próprios pacientes e de seus familiares como mais um elemento na composição de parâmetros de avaliação de resultados do tratamento ${ }^{(31)}$.

As informações acerca da percepção dos pacientes e de seus familiares a respeito dos resultados do tratamento oferecido pelos serviços de saúde têm sido compiladas em pesquisas de avaliação por meio de instrumentos de medida, denominados instrumentos PRO - PatientReported Outcomes. No Brasil, esses instrumentos são designados como Escalas de Mudança Percebida (EMP) ${ }^{(31,32)}$.

As EMP, originalmente desenvolvidas no Canadá, foram devidamente adaptadas e validadas para uso no Brasil e têm o objetivo de avaliar quantitativamente a percepção de mudanças observadas pelos próprios pacientes e por seus familiares quanto aos resultados verificados com o tratamento recebido, especialmente em face da condição clínica do paciente, de seu bem-estar físico e psicológico, de seu nível de autonomia e em relação a vida do paciente de modo geral $^{(31,33)}$.

A percepção dos pacientes como fator de avaliação dos serviços de saúde tem sido incluída nos processos avaliativos em função da relevância dessas informações, que geralmente 
não estão disponíveis entre os dados clínicos dos profissionais, como no caso de mudanças sintomáticas, de funcionamento do paciente e as mudanças relativas a seu bem-estar ${ }^{(31)}$.

O conhecimento acerca da percepção dos familiares em relação às mudanças ocorridas na vida dos pacientes com o tratamento também tem sido considerado relevante na avaliação dos serviços, na medida em que os familiares, que eventualmente ocupam a função de cuidadores diários dos pacientes, podem perceber e comunicar as eventuais mudanças observadas na vida dos pacientes, tais como, mudanças em seus sintomas, em seus níveis de funcionamento, em seus relacionamentos interpessoais e comportamentais ${ }^{(33)}$.

Essas informações também são consideradas valiosas para a avaliação dos serviços e para o aprimoramento do tratamento porque refletem conhecimento singular acerca dos sintomas, das necessidades e da vivência com os serviços de saúde, que somente os pacientes e seus familiares detêm, constituindo-se, portanto, como perspectiva diversa da concepção dos profissionais $^{(31)}$.

Destaca-se, ainda, a possibilidade de que a integração da percepção dos pacientes e de seus familiares na avaliação do tratamento contribua para a sensação de empoderamento desses atores ao perceberem que seus pontos de vista são considerados na avaliação dos resultados do tratamento, o que, por si, favorece na adesão ao próprio tratamento e no aumento dos níveis de satisfação com o serviço de saúde ${ }^{(31)}$.

Nesse sentido, a percepção de mudanças tem sido associada a questão da satisfação dos pacientes e de seus familiares com os serviços de saúde. Estudos indicaram que mudanças aferidas por profissionais, que não foram percebidas pelos pacientes como mudanças efetivamente positivas em suas vidas, não contribuem para a satisfação com os serviços de saúde ${ }^{(31,33)}$.

Com efeito, o conceito de mudança percebida adotado para a análise dos dados do presente estudo acompanhou o sentido conferido pelos desenvolvedores do instrumento de mensuração da mudança percebida, consistente em servir de indicador de avaliação de resultados do tratamento na perspectiva dos pacientes e de seus familiares.

Contudo, esse sentido instrumental da mudança percebida foi concebido neste estudo também sob a ótica do aporte teórico do método da Roda ou Paidéia, ou seja, o conceito de mudança percebida baseou-se no pressuposto de que os serviços de saúde devem se constituir como espaços coletivos orientados para promover o desenvolvimento integral das pessoas, por meio do empoderamento, da ampliação da autonomia e, consequentemente, da capacidade de análise e de intervenção das pessoas e dos coletivos sobre a própria realidade ${ }^{(25,26)}$. 
4 ASPECTOS ÉTICOS 


\section{ASPECTOS ÉTICOS}

Considerando que o respeito à dignidade da pessoa humana determina que as pesquisas envolvendo seres humanos sejam apreciadas eticamente pelas instâncias competentes e realizadas com o consentimento livre e esclarecido de todos os participantes, o presente estudo foi estritamente conduzido conforme todos os procedimentos éticos exigidos pela legislação, mormente pela Resolução 446/2012 do Conselho Nacional de Saúde. ${ }^{(34)}$

O projeto deste estudo e o respectivo termo de consentimento livre e esclarecido foram submetidos aos comitês de ética em pesquisa da Escola de Enfermagem da Universidade de São Paulo (instituição proponente) e da Secretaria Municipal de Saúde de São Paulo (instituição coparticipante), por meio do Sistema Nacional de Informação sobre Ética em Pesquisa Envolvendo Seres Humanos (SISNEP).

A Escola de Enfermagem da Universidade de São Paulo, por meio de seu comitê de ética em pesquisa, nos autos do Certificado de Apresentação para Apreciação Ética (CAAE) de número 64443717.7.0000.5392, emitiu, em 17 de março de 2017, o parecer de número 1.969.819, favorável à realização da pesquisa.

O Comitê de Ética em Pesquisa da Secretaria Municipal de Saúde de São Paulo, nos autos do CAAE de número 64443717.7.3001.0086, emitiu, em 30 de março de 2017, o parecer de número 1.990.622, também favorável à realização do estudo. 


\section{DESENVOLVIMENTO}

\section{DO PROCESSO AVALIATIVO}




\section{DESENVOLVIMENTO DO PROCESSO AVALIATIVO}

\subsection{Campo de estudo}

Em conformidade com os objetivos propostos na presente pesquisa, o campo de estudo intencionalmente definido compreendeu o CAPSad que recebeu os escores mais baixos nos instrumentos de mensuração de satisfação e de mudança percebida aplicados aos CAPSad do município de São Paulo, na esteira da pesquisa matricial intitulada "Avaliação global das necessidades individuais de usuários e dos serviços de álcool e outras drogas”, cujos dados se encontram armazenados no banco de dados do GEAD.

Essa pesquisa matricial é desenvolvida pelo GEAD, um grupo de estudos ligado ao programa de pós-graduação em enfermagem da Escola de Enfermagem da Universidade de São Paulo.

A pesquisa matricial de "Avaliação global das necessidades individuais de usuários e dos serviços de álcool e outras drogas", mensurou a satisfação dos trabalhadores, dos usuários e de seus familiares com os CAPSad por meio da Escala de Satisfação com serviços de saúde mental (SATIS- BR) ${ }^{(35)}$, bem como mensurou as mudanças percebidas nas vidas dos usuários e familiares com o tratamento oferecido pelos CAPSad, por meio da Escala de Mudança Percebida $(\text { EMP) })^{(33)}$.

A identificação do CAPSad que apresentou os escores mais baixos dentre os serviços avaliados no município de São Paulo foi realizada mediante a classificação desses escores, que se encontram armazenados no banco de dados do GEAD.

Para realizar a classificação dos escores mais baixos foram considerados os valores das medianas das variáveis relativas à satisfação dos profissionais, dos usuários e dos familiares, além das medianas acerca da mudança percebida dos usuários e familiares.

A mediana pode ser definida como o número que se encontra no centro de uma série de números dispostos segundo ordem de grandeza e tem a propriedade de não sofrer influência de valores extremos, como ocorre com a média. Essa peculiar propriedade da mediana faz com que seu valor se mantenha, apesar da eventual existência de valores extremos ${ }^{(36)}$.

A fim de evitar eventual estigmatização do CAPSad classificado como aquele que apresentou os escores mais baixos dentre os serviços avaliados no município de São Paulo, bem como visando evitar incitar possível rivalidade entre os serviços classificados, a presente pesquisa teve o cuidado de preservar a identidade dos CAPSad, codificando-os, aleatoriamente, por números de 1 a 12 . 
A tabela 1 apresenta as medianas obtidas com os escores globais da SATIS-BR aplicada aos profissionais dos 12 CAPSad do município de São Paulo/SP. Nessa tabela 1, verifica-se que o CAPSad 7 apresentou a pior mediana $(3,41)$ para a SATIS-BR.

Tabela 1 - Medianas obtidas com os escores globais da SATIS-BR aplicada aos profissionais nos anos de 2013 a 2014, segundo 12 CAPSad do Município de São Paulo.

\begin{tabular}{cc}
\hline CAPSad & SATIS -BR \\
\hline 1 & 3,98 \\
2 & 3,69 \\
3 & 3,8 \\
4 & 3,48 \\
5 & 3,95 \\
6 & 3,45 \\
7 & 3,41 \\
8 & 3,84 \\
9 & 3,83 \\
10 & 3,81 \\
11 & 4,25 \\
12 & 3,63 \\
\hline
\end{tabular}

Fonte: Banco de dados do GEAD.

Na tabela 2, observam-se as medianas obtidas com os escores globais da SATIS-BR e da EMP aplicadas aos usuários dos 12 CAPSad do município de São Paulo/SP. Nesta, verificase que o CAPSad 3 apresentou a pior mediana $(4,25)$ na SATIS-BR e também exibiu a pior mediana (2,3611) na EMP. 
Tabela 2 - Medianas obtidas com escores globais da SATIS-BR e da EMP aplicadas aos usuários nos anos de 2013 a 2014, segundo 12 CAPSad do Município de São Paulo.

\begin{tabular}{ccc}
\hline CAPSad & SATIS-BR & EMP \\
\hline 1 & 4,7083 & 2,5833 \\
2 & 4,5000 & 2,5556 \\
3 & 4,2500 & 2,3611 \\
4 & 4,7917 & 2,6944 \\
5 & 4,5000 & 2,6667 \\
6 & 4,6667 & 2,8889 \\
7 & 4,5000 & 2,8611 \\
8 & 4,7500 & 2,4167 \\
9 & 4,7500 & 2,7778 \\
10 & 4,7500 & 2,7222 \\
11 & 4,7917 & 2,8889 \\
12 & 4,6667 & 2,8333 \\
\hline
\end{tabular}

Fonte: Banco de dados do GEAD.

A tabela 3 apresenta as medianas obtidas com os escores globais da SATIS-BR e da EMP aplicadas aos familiares e aos usuários dos 12 CAPSad. Nesta, o CAPSad 3 exibiu a pior mediana tanto na SATIS-BR $(4,125)$, quanto na EMP $(2,2778)$.

Tabela 3 - Medianas obtidas com escores globais da SATIS-BR e da EMP aplicadas aos nos anos de 2013 a 2014, segundo 12 CAPSad do Município de São Paulo.

\begin{tabular}{ccc}
\hline CAPSad & SATIS-BR & EMP \\
\hline 1 & 4,250 & 2,5000 \\
2 & 4,125 & 2,7778 \\
3 & 4,125 & 2,2778 \\
4 & 4,250 & 2,5556 \\
5 & 4,250 & 2,7222 \\
6 & 4,750 & 2,9444 \\
7 & 4,125 & 2,5556 \\
8 & 4,438 & 2,6944 \\
9 & 4,500 & 2,6111 \\
10 & 4,500 & 2,7222 \\
11 & 4,125 & 2,4444 \\
12 & 4,500 & 2,6944 \\
\hline
\end{tabular}

Fonte: Banco de dados do GEAD. 
A soma das medianas obtidas com os escores globais da EMP, aplicada aos usuários e familiares nos 12 CAPSad do município de São Paulo/SP, apresentou o CAPSad 3 com a soma mais baixa $(4,6389)$, conforme demonstrado na tabela 4 .

Tabela 4 - Soma das medianas obtidas com os escores globais da EMP aplicada aos usuários e familiares nos anos de 2013 a 2014, segundo 12 CAPSad do Município de São Paulo.

\begin{tabular}{cc}
\hline CAPSad & EMP \\
\hline 3 & 4,6389 \\
1 & 5,0833 \\
4 & 5,1111 \\
2 & 5,25 \\
11 & 5,3333 \\
5 & 5,3333 \\
9 & 5,3889 \\
7 & 5,3889 \\
10 & 5,4167 \\
12 & 5,4444 \\
6 & 5,5278 \\
\hline
\end{tabular}

Fonte: Banco de dados do GEAD.

Em relação à soma das medianas obtidas com os escores globais da SATIS-BR, aplicada aos profissionais, usuários e familiares nos 12 CAPSad do município de São Paulo/SP, o CAPSad 7 apresentou a pior soma $(12,035)$, sendo imediatamente seguido pelo CAPSad $3(12,175)$, de acordo com a tabela 5 . 
Tabela 5 - Soma das medianas obtidas com os escores globais da SATIS-BR aplicada aos profissionais, usuários e familiares nos anos de 2013 a 2014, segundo 12 CAPSad do Município de São Paulo.

\begin{tabular}{cc} 
CAPSad & SATIS-BR \\
\hline 7 & 12,035 \\
3 & 12,175 \\
2 & 12,315 \\
4 & 12,5217 \\
5 & 12,7 \\
12 & 12,7967 \\
6 & 12,8667 \\
1 & 12,9383 \\
8 & 13,0275 \\
10 & 13,06 \\
9 & 13,08 \\
11 & 13,1667 \\
\hline
\end{tabular}

Fonte: Banco de dados do GEAD.

Com efeito, na classificação dos escores das variáveis analisadas na avaliação dos 12 serviços de atenção psicossocial em álcool e drogas, o CAPSad 3 exibiu a maior frequência de medianas mais baixas, configurando-se, portanto, como o campo de realização da presente pesquisa.

O CAPSad 3 trata-se de um Centro de Atenção Psicossocial II - Álcool e Drogas. Segundo a portaria que define e normatiza o funcionamento dos serviços de atenção psicossocial, os CAPSad II são serviços públicos de saúde mental voltados para o atendimento de usuários acometidos de sofrimento mental decorrente do uso e da dependência de substâncias psicoativas. Os CAPSad II são estabelecidos em municípios com população superior a 70000 habitantes ${ }^{(12)}$.

O prédio utilizado pelo CAPSad 3 é do tipo sobrado residencial. Na área da garagem, estão estabelecidas a recepção do serviço e a sala de atendimento do plantão de acolhimento, além de uma sala de espera.

No pavimento superior, o CAPSad 3 dispõe de uma sala de estar com sacada, utilizada para a convivência dos usuários; uma sala destinada às consultas médicas (clínicas e psiquiátrica); uma sala de enfermagem e uma sala para a realização de grupos, além de dois sanitários para os usuários. 
Nos fundos do prédio do CAPSad 3, há uma edícula com dois pavimentos. Em seu pavimento térreo, há três cômodos, sendo um utilizado pela farmácia do serviço, outro como sala de ateliê e de realização de grupos e o outro como copa, cozinha e refeitório dos profissionais do serviço. Já no pavimento superior da edícula, existe um depósito, uma sala utilizada para as reuniões da equipe e a sala da gerência, além de um sanitário para uso dos profissionais.

O prédio onde está estabelecido o CAPSad 3 não dispõe de acessibilidade para usuários com mobilidade reduzida, seja em função da ausência de rampas ou de elevadores, seja em função da ausência de banheiros adaptados.

O CAPSad 3 também gerencia uma Unidade de Acolhimento Adulto (UAA), que oferece acolhimento transitório aos usuários de ambos os sexos por um período de até seis meses. A unidade dispõe de dez vagas, sendo sete destinadas a homens e três reservadas para mulheres.

O CAPSad 3 é administrado por uma Organização Social de Saúde por meio de contrato de gestão celebrado com a Secretaria Municipal de Saúde de São Paulo.

Os contratos de trabalho celebrados entre o CAPSad 3 e os trabalhadores são regidos pela Consolidação das Leis do Trabalho (CLT).

O serviço funciona de segunda à sexta-feira, das $7 \mathrm{~h}$ às 19 horas e conta com um quadro funcional formado por 25 trabalhadores, sendo dois assistentes sociais, três auxiliares de enfermagem, quatro auxiliares administrativos, dois médicos clínicos, um assistente administrativo, dois oficineiros, uma técnica de farmácia, dois enfermeiros, dois terapeutas ocupacionais, um médico psiquiatra, três psicólogos, uma gerente e uma farmacêutica. Além dos 25 trabalhadores, o CAPSad 3 conta com o serviço de profissionais de vigilância e de limpeza.

A equipe de trabalhadores do CAPSad 3 está de acordo com o estabelecido nas normas dos CAPSad II, que determinam que a equipe mínima para atuação seja composta por um psiquiatra; um enfermeiro; um médico clínico; quatro profissionais com nível superior entre as áreas: psicologia, serviço social, enfermagem, terapia ocupacional, pedagogia ou outro profissional que seja necessário para o projeto terapêutico dos usuários; seis profissionais de nível médio, entre técnicos ou auxiliares de enfermagem, técnicos administrativos, técnicos educacionais e $\operatorname{artesãos}^{(12)}$.

O CAPSad 3 também realiza as atividades prescritas na norma ${ }^{(12)}$, porquanto oferece aos usuários atendimentos individuais (psicoterapia, administração de medicamentos, orientações gerais); atendimentos em grupos (grupos psicoterápicos, grupos operativos, 
atividades de apoio social); atendimentos em oficinas; visitas domiciliárias; atendimento às famílias; atividades comunitárias visando a reinserção social dos usuários; provê refeições a eles; e disponibiliza atendimentos para desintoxicação dos usuários.

\subsection{Organização da avaliação}

Uma vez identificado o campo de pesquisa, qual seja, o CAPSad 3, iniciou-se a etapa de organização da avaliação.

Nessa etapa, em meados do mês de janeiro de 2017, foram solicitadas formalmente as devidas autorizações administrativas para a realização da pesquisa no CAPSad 3, enviando-se o respectivo projeto à Coordenadoria Regional de Saúde da circunscrição do CAPSad 3 (da Secretaria Municipal de Saúde de São Paulo), iniciando o fluxo processual atinente aos projetos de pesquisa.

Após a aprovação administrativa da Coordenadoria Regional de Saúde para encaminhamento do protocolo de pesquisa à apreciação ética, ainda no mês de janeiro de 2017, submeteu-se o projeto à "Plataforma Brasill", dando seguimento ao processo ético junto aos comitês de pesquisa da Escola de Enfermagem da Universidade de São Paulo e da Secretaria Municipal de Saúde de São Paulo.

Em meados do mês de abril de 2017, na posse das autorizações administrativas e dos respectivos pareceres éticos favoráveis, foi realizado o primeiro contato com o campo de pesquisa. Nesse primeiro encontro, o pesquisador foi recebido pela gerente do CAPSad 3, a qual, após ser devidamente esclarecida acerca dos objetivos e da metodologia da pesquisa, franqueou totalmente o acesso ao serviço para o pesquisador, facultando-lhe empreender a coleta dos dados da pesquisa em quaisquer dias e horários de funcionamento do serviço.

Após o primeiro contato com o campo, ainda no mês de abril de 2017, iniciou-se, efetivamente, o procedimento de coleta de dados, o qual, , correspondeu à construção de uma relação de confiança entre o pesquisador e os interessados na avaliação, com vistas a conquistar o "direito de entrada" no campo de pesquisa.

Ainda nesse momento inicial, o pesquisador procurou vivenciar o contexto dos interessados, buscando interagir com eles para conhecê-los e ser por eles conhecido. Essa interação do pesquisador com o campo de pesquisa correspondeu à denominada "etnografia prévia"(23). 
As observações de campo totalizaram 85 (oitenta e cinco) horas de registros em diário de campo, realizados nos 25 (vinte e cinco) dias em que o pesquisador esteve pessoalmente no serviço.

\subsection{Identificação dos grupos de interesse}

A partir da vivência do avaliador no campo, própria da etapa anterior (etnografia prévia), foram identificados três grupos de interesse no CAPSad 3, quais sejam, grupo de profissionais, grupo de usuários e grupo de familiares.

\subsection{Desenvolvimento das construções conjuntas}

Identificados os grupos de interesse, seguiu-se para o desenvolvimento das construções conjuntas, ou seja, o momento da aplicação do CHD, realizando-se um círculo para cada grupo de interesses.

O círculo do grupo de profissionais compreendeu a participação de oito trabalhadores do CAPSad, tendo sido composto por dois auxiliares de enfermagem, uma terapeuta ocupacional, a gerente do serviço, uma oficineira, um psiquiatra e dois psicólogos. O círculo do grupo de usuários contou com dez participantes e no círculo do grupo de familiares houve a participação de seis familiares.

\subsection{Ampliação das construções conjuntas}

A introdução de informações para aumentar o nível de esclarecimento dos participantes ocorreu durante a aplicação do CHD, visando a ampliação das construções emergentes. Essas informações foram originárias das observações do pesquisador e da literatura profissional.

\subsection{Preparação da apresentação das questões para os grupos de interesse}

Nessa etapa, os participantes de cada círculo (profissionais, usuários e familiares) foram convidados para a realização das entrevistas em grupo, sendo agendadas três datas e horários para a realização de uma entrevista grupal com cada círculo. 
O pesquisador preparou material impresso, contendo as unidades de informações agrupadas em núcleos temáticos, para distribuir aos participantes, a fim de que eles pudessem acompanhar a exposição dos resultados provisórios da avaliação.

Ainda nessa etapa, o pesquisador convidou uma experiente pesquisadora (professora doutora e pós-doutoranda) para proceder à observação da realização dos grupos, tomando notas pertinentes a respeito da dinâmica grupal.

\subsection{Realização dos grupos}

A realização dos grupos teve o objetivo de devolver, a cada grupo de interesse, o conteúdo das respectivas construções que emergiram durante as rodadas dos círculos hermenêutico-dialéticos de cada grupo de implicados.

Tratou-se, portanto, do momento da validação dos resultados provisórios, relativos às construções resolvidas (compartilhadas).

Nessa fase, também se realizou com os grupos de interesse a negociação das construções conflitantes, objetivando o consenso.

A realização dos três grupos ocorreu em meados do mês de junho de 2017.

Os encontros foram realizados em sala previamente reservada para tal e contou com a participação da pesquisadora convidada para realizar a observação e o registro de suas considerações sobre a dinâmica apresentada por cada grupo.

O grupo dos profissionais contou com a participação de todos os oito entrevistados (respondentes) do círculo dos profissionais.

Já no grupo de usuários, houve a participação de sete, dos 10 entrevistados (respondentes) do círculo dos usuários.

Com relação ao grupo de familiares, cinco dos seis respondentes do CHD participaram do encontro.

A todos os participantes dos grupos foi entregue material impresso, contendo as unidades de informação devidamente agrupadas em núcleos temáticos para que pudessem acompanhar a leitura e discutir cada item apresentado.

Com o escopo de assegurar a confidencialidade das informações da pesquisa, ao término de cada um dos grupos, todo o material entregue no seu início foi devidamente devolvido pelos participantes ao pesquisador. 
6 RESULTADOS E DISCUSSÃO 


\section{RESULTADOS E DISCUSSÃO}

A transcrição dos relatos dos participantes da pesquisa foi inserida ao longo da explanação dos resultados e discussão de modo a preservar o anonimato dos colaboradores. Os relatos foram transcritos na íntegra, exatamente da maneira como foram pronunciados, sem as convenções da língua padrão, inclusive sem o uso de vírgulas e demais pontos gramaticais. Os relatos foram codificados com siglas, adicionadas ao final, conforme os seguintes padrões:

- $\quad\left(\mathrm{E} \mathrm{n}^{\mathrm{o}} \mathrm{P}\right)$, significando: transcrição da entrevista com o número de ordem de sua realização de um profissional do serviço;

- $\quad\left(E n^{\circ} \mathrm{U}\right)$, significando: transcrição da entrevista com o número de ordem de sua realização de um usuário do serviço;

- $\quad\left(E n^{o} F\right)$, significando: transcrição da entrevista com o número de ordem de sua realização de um familiar atendido no serviço;

- (GP), significando: transcrição da entrevista em grupo realizada com os profissionais do serviço;

- $(\mathrm{GU})$, significando: transcrição da entrevista em grupo realizada com os usuários do serviço;

- (GF), significando: transcrição da entrevista em grupo realizada com os familiares atendidos do serviço.

\subsection{Avaliação da satisfação dos profissionais}

A satisfação dos profissionais do CAPSad apresentou um espectro de significados e sentidos durante todo o processo do CHD, resultando na tematização de seu conteúdo em três núcleos, ora denominados como "clínica", "gestão" e "ensino".

\subsubsection{Núcleo Temático Clínica}

O núcleo temático "clínica" abrange os desdobramentos acerca da satisfação construídos pelo grupo de profissionais no que tange à esfera da assistência em saúde empreendida pela equipe no cotidiano do serviço. 
Os aspectos relativos à satisfação dos trabalhadores, trazidos pelo respectivo grupo no contexto da assistência, revelaram-se ambivalentes, oscilando tanto no sentido de constituir-se como atividade geradora de satisfação, como também representar óbice para a promoção de satisfação dos trabalhadores.

Os pontos da assistência oferecida pela equipe aos usuários do CAPSad, tidos por consenso pelo grupo de profissionais como uma experiência produtora de satisfação, referemse às atribuições ordinárias do serviço, mormente quando se apercebem ou acreditam que seus esforços são responsáveis por transformações positivas nos aspectos gerais da vida dos usuários do serviço, conforme as seguintes colocações:

Eu sinto muita satisfação quando faço grupos tanto com os usuários como com os familiares né eu acho que eu sinto muita satisfação [...] eu acho que quando eu consigo articular alguns pontos com a rede né seja a rede de saúde seja a rede intersetorial e eu acho que quando a gente consegue algum resultado é talvez esse resultado não seja uma abstinência total mas é algum tipo de cuidado pro usuário acho que isso aumenta a satisfação e isso dá um pouco mais de gás para continuar. (E2P)

Gosto do que faço muito a saúde mental pra mim abriu muito a minha própria mente e fez eu conhecer melhor é um crescimento profissional né. (E3P)

Quando você vê que o que você fala que as reflexões que você tenta trazer tão trazendo de alguma forma uma mudança na pessoa e que você traz algum apoio ou você traz algum acréscimo pra elas isso é muito gratificante mesmo [...] quando eu vejo que a pessoa tá se desenvolvendo eu fico muito feliz de ver que meu trabalho tem um sentido sabe eu acho que o que me deixa feliz aqui é isto ver sentido no que estou fazendo. (E4P)

Hoje pra mim o Caps tem uma importância muito grande e eu não gostaria de sair de forma alguma então hoje eu aqui estou muito satisfeito financeiramente eu acho que ainda deixa um pouco a desejar mas eu gosto do que eu faço e no meu trabalho eu consigo ver um resultado sabe eu consigo ver o que eu faço se tornar um diferencial na vida deles e isso é muito bom isso é muito gratificante. (E5P)

Eu gosto muito do trabalho daqui é um lugar que eu me sinto bem tanto com a equipe em si tanto com os usuários com as pessoas que frequentam esse espaço [...] generalizando de uma maneira geral eu me sinto satisfeita. (E7P)

Me traz uma maior satisfação porque eu vejo casos aqui que tiveram uma evolução assim tremenda de acompanhamento. (E8P)

Conforme se verifica nas falas, os profissionais observaram desenvolvimento dos usuários, o que ensejou ao grupo de profissionais experiências de satisfação, verbalizadas também como gratificação e felicidade.

Além de ser admitida como fonte de satisfação consensual pelo grupo de profissionais, a percepção, por parte da equipe, de que seu trabalho assistencial beneficiou os usuários do 
serviço também foi considerada como determinante de estímulo e motivação para seguir trabalhando no CAPSad.

A satisfação relatada pelos profissionais, proveniente da percepção de que seus esforços na clínica engendraram mudanças positivas na vida dos usuários está associada ao efeito Paidéia, ou seja, na ampliação da capacidade de análise e de intervenção dos grupos por meio da participação dos usuários nos espaços coletivos ${ }^{(25,26)}$.

Essa satisfação decorrente da percepção de mudanças positivas na vida dos usuários evidencia que o grupo de profissionais do CAPSad trabalha na perspectiva de desenvolvimento integral dos usuários - função Paidéia, trabalhando com eles (e não sobre eles) no sentido de ampliar suas capacidades de autoanálise, de análise do contexto e de intervenção sobre si mesmos e sobre seu contexto, em clara oposição aos arranjos organizacionais dirigidos à objetivação dos sujeitos - função anti-Paidéia ${ }^{(25,26)}$.

Outros pontos narrados consensualmente pelo grupo de trabalhadores como fontes de satisfação acerca da assistência em saúde, estão relacionados à dinâmica do trabalho clínico do CAPSad constituir-se em equipe multidisciplinar e à característica de que a clínica promovida no serviço não estaria adstrita a rígidos e pré-determinados procedimentos técnico-assistenciais, mas suscetível a modulações, a arranjos e a diferentes possibilidades de manejos, de acordo com as seguintes posições:

A oportunidade de trabalhar aqui pra mim tá sendo muito muito rica mesmo assim eu tô aprendendo muitas coisas tanto com a equipe que é multidisciplinar quanto com os próprios usuários quanto com meu próprio desenvolvimento. (E4P)

O que me motiva e que me dá satisfação de trabalhar no Caps é a possibilidade de interagir dentro de uma equipe multidisciplinar eu acho que num primeiro momento a possibilidade de trocar de aprender de discordar e de conviver com outros profissionais de diferentes referências teóricas práticas então a possibilidade da troca é uma coisa muito rica e que me motiva [...] a questão do desafio né a questão de você muitas vezes pensar intervenções que muitas vezes são construídas através dessa articulação através dessa troca entre os profissionais que trabalham nessa equipe né o desafio é porque não existe uma coisa posta não existe uma coisa fechadinha pra quem trabalha com essa população principalmente no contexto do SUS então quando eu vou pra clínica privada quando eu vou pra clínica particular pra mim é muito evidente essa diferença [...] o que me atrai o que me faz aproximar do trabalho no Caps é a possibilidade de tá sempre revendo conceitos preestabelecidos a todo momento rever condutas intervenções princípios e queira sim queira não a gente sempre está se reinventando aprendendo se reciclando [...] um dia nunca vai ser igual ao outro e as demandas podem ser parecidas mas elas podem ter suas peculiaridades então pra mim isso é muito excitando a questão de se adequar a novos contextos a novos desafios é enriquecedor. (E6P) 
Eu fico mais feliz aqui porque eu vejo que a equipe consegue sair de um automático sair de uma organização do papel sair de algo muito programático pra fazer ações mais reais e de maior proximidade com o paciente [...] isso me traz satisfação assim isso me enriqueceu como pessoa [...] eu vejo que não existe uma acomodação na equipe o que eles precisarem fazer eles vão fazer e isso eu acho um ponto muito positivo e que traz uma satisfação muito grande [...] pensar realmente no cuidado além do uso de drogas [...] então às vezes a gente discute um caso só pra falar de um rapaz que tá com problema de hepatite e como a gente poderia ajudá-lo [...] a droga ficou em segundo plano nesse momento e tudo bem você tá cuidando dele da mesma forma eu acho que não é porque eu sou Capsad que eu não vou falar das outras questões de vida desse paciente e isso assim nesse sentido me traz uma satisfação. (E8P)

Eu gosto do fato de que aqui não tem um roteiro estabelecido do que você deva fazer ou não fazer assim é tudo muito aberto a gente vai conversando vai construindo juntos como fazer algo ou não fazer algo a gente pode experimentar trazer coisas novas [...] tem liberdade pra exercer o que a gente faz sabe isso eu acho legal não é uma coisa de cima pra baixo (GP)

O trabalho em equipe multidisciplinar e a perspectiva de clínica em construção (flexível), concebidas pelo grupo de profissionais como circunstâncias promotoras de satisfação associa-se à noção de obra - do método Paidéia, a qual corresponde a integração dos desejos e interesses dos trabalhadores no processo de trabalho ${ }^{(25)}$.

Consoante o método Paidéia, a produção de obras possibilitaria experiências de realização pessoal por parte dos trabalhadores no processo laboral, conquanto que seus desejos e interesses pessoais estivessem presentes no desenvolvimento do trabalho cotidiano. Para o autor do método, tanto o desejo (ligado ao prazer e ao gozo), quanto o interesse (referente à sobrevivência das pessoas) dos profissionais devem estar integrados ao trabalho (caráter antiTaylor), sob pena de estabelecer-se relação laboral típica da racionalidade hegemônica tradicional, que preconiza a concentração dos desejos e interesses dos trabalhadores, particularmente, na remuneração ${ }^{(25)}$.

Não obstante a incorporação dos desejos e interesses dos trabalhadores ao processo de trabalho, há a necessidade da participação efetiva dos trabalhadores em todas as etapas do processo de trabalho, de modo que a ideia de produção de obras vincula-se à ampliação do conceito de resultados do trabalho ${ }^{(25)}$.

Os resultados do trabalho, para o método da Roda, devem ser entendidos de maneira ampliada, não se confundindo com o resultado final: o produto ou serviço. Ao contrário, os resultados do trabalho devem ser compreendidos como o conjunto de efeitos produzidos no curso do processo de trabalho, englobando desde a concepção dos projetos até a sua execução, facultando aos trabalhadores o direito a participação em todas as fases do processo de trabalho ${ }^{(25)}$. 
Se por um lado, o grupo dos profissionais expressou satisfação de trabalhar no CAPSad em função da realização das atividades ordinárias do serviço, da composição multidisciplinar da equipe e da característica da clínica em processo de construção; por outro lado, o mesmo grupo apresentou fatores que não contribuiriam para sua satisfação, consoante as seguintes falas:

Porque eu acho que o nosso trabalho na saúde mental, no Caps álcool e drogas, ele, ele é muito denso né. Eu acho que trabalhar com crise principalmente relacionada à ingestão de substâncias né pacientes intoxicados acho que por mais que a gente se aprimore por mais que a gente de qualifique [...] eu acho que a gente tem um tempo de atuação na ponta enquanto trabalhador né de um Caps álcool e drogas especificamente porque mesmo que o trabalhador tenha os cuidados necessários, busque algum tipo de autocuidado né terapia aprimoramento mas eu acho que vai tendo ao longo do tempo um esgotamento. (E1P)

É um trabalho que exige muito de você eu até comento que eu não sei como tem pessoas aqui tipo há oito anos trabalhando oito horas por dia porque eu acho muito insalubre [...] tem dias que eu venho aqui meio desligada porque eu já fui exaurida a semana inteira e aí você tem que vir um pouco mais porque você não lida só com o uso de drogas que já é difícil você lida com tudo com problema social você lida com apoio emocional. (E4P)

Os nossos pacientes dependentes químicos as relações deles são muito orais no sentido de que eles têm dificuldade pra se saciar com as coisas então se aquela pessoa se disponibiliza e não consegue estabelecer um limite aquela relação com o usuário vai consumir o profissional e as vezes quando você tá numa equipe multidisciplinar você consegue diluir isso entendeu e outra coisa quando você estabelece uma relação muito passional muito individualizada com aquele usuário a primeira pessoa que for por limite nesse tipo de relação oral o paciente começa a se relacionar de uma maneira parcial com os outros profissionais do tipo este é meu amigo este aqui não me atende nas minhas demandas ele começa a cindir a equipe. (E6P)

$70 \%$ a $80 \%$ da população que a gente atende aqui é população de rua né até pela nossa proximidade com o centro de acolhida tanto masculino como feminino e é uma população com uma característica difícil né difícil de lidar difícil estabelecer algumas regras né é uma população que muito solicita né pouco devolve né então eles vem muito solicitando eu quero comer eu quero dormir eu quero roupa eu quero dinheiro eu quero isso eu quero aquilo muito solicitante e com uma dificuldade de entender o papel do Caps e aí você tem que a todo momento reforçar olha não é esse o papel nosso de dar coisas pras pessoas é um processo de elaboração a gente oferece um tratamento que é médico que é psicológico então a gente tem uma dificuldade realmente de lidar com essa população e eles não têm uma compreensão né do negativo a frustração é muito grande nessa clínica também né quando você diz um não o não toma um proporção muito grande e aí eles vêm intoxicados pra agredir a equipe então a gente já teve várias situações que a gente teve que baixar o portão infelizmente chamar a ajuda da gcm por estar sendo ameaçado mesmo. (E8P) 
É muito fácil você cindir a equipe em pessoas a seu favor e pessoas contra seu favor o dependente químico naturalmente já traz essa história de cisão para dentro do Caps e ele tenta reproduzir isto na equipe e se ele encontra terreno fértil acaba acontecendo esse tipo de situação (GP)

Como observado nas falas, o grupo de profissionais considerou o tempo prolongado de atuação no serviço e algumas características relativas ao perfil dos usuários do CAPSad como especificidades que não favoreceriam a satisfação dos trabalhadores.

Em relação ao tempo de atuação no serviço, o grupo de profissionais levantou a preocupação de que o trabalho prolongado na "ponta" - diretamente com o público, pode gerar um esgotamento no profissional, frustrando suas possibilidades de satisfação no período de longo prazo nessa mesma posição de atuação.

Essa preocupação do grupo com o horizonte profissional, dos limites temporais de atuação na "ponta", foi dirimida por alguns trabalhadores (e não pelo consenso grupal) por meio de organização pessoal (preparação para alcance de propósitos individuais) com a perspectiva de ascender a cargos de gestão formal do serviço, conforme verifica-se nas seguintes afirmações:

Então propus essa mudança justamente para que eu pudesse né ao longo do tempo em médio prazo aí pensar numa outra, num outro lugar dentro da instituição visando muito mais essa questão da coordenação, de algum dia sair dessa condição de trabalhador da ponta para poder né a partir da experiência adquirida e a partir enfim da minha capacitação que eu fui tendo ao longo do tempo, assumir uma função né, na área da gestão. (E1P)

Eu almejo um cargo de gestão pela minha experiência pela minha trajetória eu acho que eu tenho possibilidade e eu acho que além dessa questão de almejar um cargo de gestão mas não só de benefício individual no sentido salário mas eu acho que poderia contribuir pra que o Caps seja mais uma questão intersetorial que se converse e eu acho que eu tenho uma sensibilidade pra lidar com os profissionais assim eu acho que eu tenho essa questão de escuta uma escuta talvez democrática isso vem na minha cabeça constantemente e de certa forma eu tenho me preparado pra isso [...] é uma coisa que eu tenho pro futuro assim um desejo. (E2P)

Entre as características do perfil dos usuários do CAPSad, citadas como negativas ao fomento da satisfação da equipe, foram mencionadas pelo grupo de profissionais, basicamente e em confluência: a carência socioeconômica dos usuários e a dificuldade dos profissionais de estabelecer limites ao comportamento dos usuários.

A convergência entre a carência socioeconômica dos usuários e a dificuldade em estabelecer limites os usuários foi levantada pelo grupo de profissionais como uma dificuldade no cotidiano de trabalho da equipe. 
O grupo de profissionais relatou atender uma demanda de usuários que, em sua maioria, é proveniente do Centro de Acolhida - instituição municipal que oferece acolhimento provisório para pernoite, existente no território e que, portanto, está em situação de rua e, geralmente, afastada de suas famílias.

O grupo narrou, ainda, a dificuldade de lidar com as demandas imediatistas e gerais por parte dos usuários, em contraste com os recursos restritos e próprios de um serviço público de saúde mental em álcool e outras drogas.

As dificuldades apontadas pelo grupo de profissionais, além de constituírem-se como embargo para a satisfação dos trabalhadores, foram apontadas como possíveis causas de adoecimento dos profissionais envolvidos. A respeito da possibilidade da ocorrência desse adoecimento, o grupo de profissionais convencionou chamar de "personalização" do atendimento, como pode-se notar nas falas:

$\mathrm{O}$ esgotamento é maior naqueles profissionais que centralizam muito as condutas as ações em cima deles entendeu eu acho que quando você trabalha numa equipe multidisciplinar e você sabe descentralizar as ações o peso do esgotamento emocional é menor mas tem profissionais que mesmo trabalhando numa equipe multidisciplinar são muito centralizadores e eles acabam adoecendo mesmo acaba adoecendo porque se eles não conseguem ter essa percepção eles acabam pagando um preço muito alto [...] personalizar é assim quando a pessoa centraliza as condutas do paciente em torno dela o paciente acaba elegendo aquele profissional como a principal referência dentro do serviço. (E6P)

O grupo de profissionais se valeu da expressão "personalização" do atendimento para designar a polarização do atendimento na pessoa de determinado profissional, que converge para si todas as responsabilidades atinentes ao atendimento do usuário, a despeito da dinâmica multiprofissional adotada pelo CAPSad.

Essa atitude de personalização do atendimento é concebida pelo grupo de profissionais como potencialmente geradora de consequências indesejadas para a saúde dos profissionais, comprometendo também sua satisfação.

A predisposição do profissional de incorrer na personalização do atendimento, conforme o entendimento do grupo de profissionais, está relacionada à própria ansiedade do profissional, suscitada pelas demandas colocadas pelos usuários no cotidiano da clínica.

Como resultado dessa relação, o grupo de profissionais apontou a tendência ao adoecimento do profissional que personifica em si toda a complexidade das demandas do usuário. 
Trazida para o grupo de profissionais na etapa de validação e de negociação do processo avaliativo, a questão da personalização do atendimento foi objeto de reflexão e de resolução (consenso) pelo grupo de interesse.

O grupo de profissionais seguiu o entendimento de que o atendimento aos usuários do serviço deve ser compartilhado por todos os membros da equipe, devendo-se evitar a concentração dos atendimentos exclusivamente na pessoa de determinado profissional, de acordo com as seguintes falas:

o que não pode acontecer na entrada de um usuário é aquela pessoa se colocar numa situação de onipotência olha eu vou cuidar de você você vai ser o meu paciente eu vou montar o seu projeto entendeu eu acho que isso é uma fala que o profissional tá trazendo pra ele uma responsabilidade que depois ele não vai que pro usuário que tá numa situação de fragilidade numa situação de crise quando alguém se coloca dessa maneira a pessoa digamos assim a tendência é ele adotar aquele sujeito como o salvador que ali vai atender todas as demandas dele então a gente tem que ter cuidado com profissionais que tem uma tendência mais centralizadora nesse sentido é uma coisa que a gente vê vez ou outra entendeu principalmente naqueles profissionais que vem de uma realidade de um contexto diferente do Caps entendeu então por exemplo profissionais que vêm da atenção básica de saúde profissionais que vêm de unidades hospitalares profissionais que vêm de uma realidade de atender a demanda de imediato entendeu então tem muitos profissionais que quando chegam no Caps eles não conseguem desenvolver o tempo né eles têm uma séria dificuldade pra lidar com a ansiedade do paciente. (E6P)

A chance do profissional adoecer é maior quando ele não divide o projeto terapêutico né as atribuições eu acho que a riqueza do nosso trabalho é essa né a gente dividir o piano entre nós dividir o peso né porque tem pacientes que são mais complexos mais graves [...] eu percebo às vezes eu me deparo com essa situações de alguns profissionais estarem mais adoecidos e uma das causas é essa eles acabam pegando e essa é uma das características da nossa clientela né dos nossos usuários essa oralidade voraz que eles têm né então se você cai naquela ansiedade de ter que atender a demanda imediata [...] eu percebo que tem alguns colegas que tem mais dificuldade de adiar de postergar [...] e acabam entrando na pilha e não conseguem adiar (GP)

Algumas pessoas tomam a frente pra lidar com a crise e talvez acabe ficando
sobrecarregadas e outras talvez não no manejo da crise e talvez isso acabe
ficando personalizado para alguns profissionais e outros não muito [...] se o
manejo é compartilhado dói menos [...] acho que se existe algo compartilhado
independente da referência do paciente eu acho que isso acaba colaborando
nesse sentido para que esse esgotamento possa diminuir um pouco. (GP)

Além do atendimento compartilhado dos usuários pelos membros da equipe, o grupo de profissionais entendeu que o manejo, para evitar a personalização do atendimento, também deve repercutir na construção do vínculo do usuário, que deve ser dirigido ao serviço como um todo e não a determinado profissional. 
Com efeito, o grupo de profissionais entendeu que ao estender o vínculo do usuário ao serviço como um todo, além de arrefecer as tendências à personalização do atendimento, o próprio usuário seria beneficiado, uma vez que a ênfase de sua vinculação ao serviço o preservaria de eventuais traumas devidos a rompimentos vinculares, em razão da possível ausência de determinado profissional (por motivos de férias, transferências, desligamento etc.), suscitando no usuário a impressão de descontinuidade do atendimento e um possível sentimento de abandono, conforme se observa na seguinte colocação:

e a gente tem que entender que os pacientes tem que se vincular queira sim queira não à instituição porque os cortes as quebras as mudanças pros pacientes podem ser muito traumáticas quando eles só conseguem interagir com determinado profissional entendeu então quando aquele profissional por alguma razão se ausenta ou por alguma razão aquele profissional é transferido ou por alguma razão aquele profissional sai do serviço pro paciente é muito traumático essa quebra do vínculo então quando a gente procura criar um vínculo com o paciente a gente tem que trazer o vínculo do paciente para à instituição. (E6P)

\subsubsection{Núcleo Temático Gestão}

O núcleo temático "gestão" procurou sintetizar as construções que emergiram no grupo de profissionais acerca da sua satisfação no âmbito da administração do serviço, notadamente nas questões relativas à definição e cumprimento de metas estabelecidas no serviço.

O grupo de interesse considerou que o implemento unilateral de metas se configura como modelo organizacional que não contribui para a satisfação dos trabalhadores, conforme assentado pelo grupo:

Os trabalhadores são a todo momento pressionados a atingir algumas metas [...] acho que isso cria uma certa pressão e uma certa ansiedade nos trabalhadores eu acho que a gente já faz isso que é determinado que é estabelecido só que isso não é quantificado né não é mensurado a partir do momento que isso passou a ser mensurado acho que foi gerando algum sentimento de angústia nas pessoas de não atingirem essas metas. (E1P)

As metas não são compartilhadas com os trabalhadores muita coisa que vai acontecendo os trabalhadores não estão envolvidos né e a gente que tá na ponto é que sente como que a coisa funciona então eu acho que esse esgotamento está relacionado com a falta de uma gestão compartilhada e democrática com os profissionais que estão na ponta [...] a falta de uma participação dos profissionais talvez nessa questão de metas acho que nesse sentido que acaba influenciando esse esgotamento maior do que deveria (E2P) 
Quando atinge a meta você não vê um elogio mas quando tá próximo do fechamento de mês aí você tem uma cobrança maior entendeu que vai gerando um desconforto em toda a equipe por ser cobrado entendeu (E3P)

O trabalho aqui no Caps tá ficando muito burocrático às vezes (E6P)

A gente é cobrado tanto na questão burocrática o tempo inteiro de que precisa bater as metas precisa fazer os atendimentos (E7P)

O grupo de profissionais considerou inadequada a elaboração de metas para o serviço sem a possibilidade de participação dos trabalhadores na construção e implementação das mesmas. $\mathrm{O}$ grupo de implicados admitiu que se sente cobrado e pressionado a cumprir as metas impostas unilateralmente e que as consequências desses sentimentos implicam em esgotamento, desconforto, ansiedade e angústia para os trabalhadores.

Além de suscitar a possibilidade de ocorrência desses sentimentos indesejados, a agenda de metas do serviço é percebida pelo grupo de profissionais como prejudicial à qualidade da assistência oferecida pelo serviço, em função das próprias metas se constituírem como instrumento de burocratização da organização do CAPSad, de acordo com as seguintes colocações do grupo:

Uma das coisas que eu sinto falta é a qualidade do serviço prestado priorizase muito o trabalho quantitativo os resultados quantitativos a gente deixa de olhar pra qualidade do atendimento então existe esse viés aí na nossa proposta de trabalho [...] quando você prioriza o trabalho quantitativo isso vai dificultar o acesso ao território então eu percebi que as saídas pro território as saídas pra construir esse trabalho mais qualitativo se perdeu um pouco [...] as saídas pro território estão cada vez menores cada vez mais escassas e hoje o trabalho está mais voltado para dentro do Caps do que pra fora eu mesmo saia muito mais [...] e também um pouco do enrijecimento a questão burocrática do ponto eletrônico isso acaba restringindo bastante você tem que justificar as saídas pro território existe todo um obstáculo pra você sair no território e fazer um trabalho de mais qualidade [...] existe uma pressão pra se atingir um número de pacientes ativos no Caps e isso implica você digamos assim esse trabalho de qualidade que me refiro é o trabalho no território matriciar se reunir com outro equipamento de saúde isso é um trabalho de qualidade. (E6P)

A gente não acompanha nenhum processo é só dito e a gente precisa fazer [...] a verdade é que tudo é muito burocrático [...] a gente não tem autonomia aqui no sentido de criar propostas novas [..] acho que nós profissionais prezamos muito a qualidade mas eu acho que a empresa em si preza mais a quantidade metas né e aí eu me deparei muito com essa situação de ter que cumprir algumas coisas de agenda e acabar deixando um pouco as coisas relacionadas mesmo ao cuidado corpo a corpo da gente com o usuário de poder cuidar de uma maneira mais integral de maneira mais dedicada. (E7P)

As metas vieram do contrato de gestão isso é uma determinação da Prefeitura não é feita uma consulta aos profissionais sobre quais deveriam ser os indicadores. (E8P) 
O anseio demonstrado pelo grupo de profissionais de participar da elaboração das metas do serviço, embora componha reivindicação consensual do grupo de interesse, foi considerado, no contexto vivido, como de ordem infactível. O grupo de profissionais ponderou que não detém a governabilidade sobre a definição das metas, que são pactuadas no contrato de gestão celebrado entre a Administração Pública Municipal e a respectiva Organização Social de Saúde que administra o equipamento de saúde, sem a possibilidade de participação dos trabalhadores envolvidos.

Ainda que considerada como inexequível em virtude da pré-pactuação das metas do serviço no contrato de gestão, a emergência da reivindicação do grupo de profissionais de participar da concepção das metas que nortearão o serviço apresenta sintonia com um dos conceitos fundamentais do método Paidéia, consistente na construção de democracia institucional $^{(25,26)}$.

O método da Roda, que se pretende anti-Taylor, ou seja, que se contrapõe ao modelo de administração científica ou da racionalidade gerencial hegemônica, depende da construção de espaços compartilhados de poder (rodas) para o exercício da participação dos interessados, caracterizando-se como regimes democráticos ${ }^{(25)}$.

A construção de espaços coletivos de poder compartilhado (com paridade de poderes), de acordo com o método da Roda ou Paidéia, tem o objetivo de assegurar aos interessados a possiblidade concreta (de tempo e de lugar) de analisar sua pauta de problemas e de tomar decisões conjuntas a esse respeito.

A gestão democrática e participativa (cogestão), como eixo do método da Roda, tem a finalidade de ampliar a capacidade de direção de todos os trabalhadores e não somente da cúpula da instituição, com vistas a desenvolver, nos trabalhadores, habilidades para a composição de consensos, de alianças e de elaboração de projetos, tendendo a diminuir a distância entre governantes e governados ${ }^{(25)}$.

Como no caso concreto, o autor do método da Roda frisa que o desenvolvimento da instituição no sentido da implantação de gestão democrática está condicionado, além de uma transformação de caráter intelectual e moral nas pessoas envolvidas, à necessidade de embasamento legal para assegurar sua implantação e manutenção ${ }^{(25)}$. 


\subsubsection{Núcleo Temático Ensino}

O núcleo temático "ensino" aborda a percepção do grupo de profissionais a respeito da carência de investimentos por parte da gestão no desenvolvimento da educação permanente dos trabalhadores.

Essa percepção de falta de investimento em educação permanente, admitida consensualmente pelo grupo de profissionais como imprescindível ao desenvolvimento profissional, em razão de necessidades de natureza pedagógico-terapêuticas, também foi reconhecida como obstáculo para o incremento da satisfação dos trabalhadores, de acordo com as seguintes manifestações:

Muitas vezes esses congressos são custeados pelos próprios profissionais né não existe nenhum tipo de investimento ou apoio ou autorização né a gente na maioria das vezes quando a gente propõe uma educação permanente é custeado pelo próprio trabalhador [...] isso tem uma relação direta com a insatisfação, a partir do momento em que não há por parte da instituição e da própria Secretaria de Saúde um investimento em educação permanente. (E1P)

Tanto a Organização Social quanto a gestão do serviço não se preocupam com isso as vezes até alguns profissionais ficam sabendo de palestras de cursos mas eles são meio que podados porque ah tem que pagar banco de horas não tem como liberar então eu acho que as pessoas estão muito presas na assistência [...] e esta questão da capacitação fica uma questão secundária ou até terciária assim no serviço e isto acaba deixando os profissionais acho que gerando uma angústia porque você tá na assistência mas você acaba não se atualizando não sabendo o que está acontecendo de novo [...] a gente vai por conta própria [...] não tem nenhum investimento não tem nenhum movimento da gestão nesse sentido. (E2P)

a gente tem poucos cursos e acho que às vezes vem cursos muito pro pessoal da enfermagem de capacitação de doenças de vacinas [...] mas que não atende a gente da saúde mental a gente não fala sobre crise a gente não fala sobre contenção a gente não fala sobre o cuidado humanizado sobre acolhimento então a gente precisava discutir essas coisas. (E7P)

Conforme pode-se constatar nas falas, além do grupo de profissionais expressar sua reivindicação por educação permanente, também manifestou que os ônus do investimento em eventos, cursos de capacitação e de aperfeiçoamento recaem exclusivamente sobre os trabalhadores. Essas circunstâncias convergem como causas que não contribuem para a satisfação dos profissionais.

Essa carência de investimento em educação permanente destoa do preconizado pela Política Nacional de Educação Permanente em Saúde (PNEPS), no sentido de propor o planejamento, a formação e a educação permanente dos trabalhadores em saúde nas três esferas de gestão do Sistema Único de Saúde (SUS). 
Ainda com relação à reivindicação de educação permanente, o grupo de profissionais, na etapa de validação e de negociação do processo avaliativo, construiu o consenso a respeito da necessidade primordial de acesso à supervisão institucional, de acordo com as seguintes colocações:

O que eu mais sinto falta nesse nosso trabalho é a supervisão a capacitação eu até relevo mas eu acho que não dá pra funcionar um serviço de saúde mental sem uma supervisão pra fazer apontamentos entendeu então pra mim não vai ser eu quem vai chegar pra um colega e vou fazer apontar isso porque nem todos têm o discernimento e o preparo pra encarar isso de uma maneira saudável pode ser que aquele colega desenvolva uma certa persecutoriedade né então pra mim acho que a capacitação a gente pode até buscar fora mas a supervisão é uma coisa que a gente não deveria abrir mão principalmente na área de saúde mental [...] pra nós que trabalhamos com reabilitação e reinserção social sem supervisão viu a gente adoece muito mais fácil. (E6P)

A supervisão é o que a gente em equipe fala muito né a gente nós enquanto equipe gostaríamos assim de ter uma supervisão tanto institucional quanto uma supervisão desses casos que às vezes são mais difíceis da gente conseguir lidar. (E7P)

Eu sinto falta já teve em algum momento inclusive tem em alguns outros Caps que é a supervisão institucional assim de poder às vezes trazer alguns questionamentos né algumas situações que a gente se vê um pouco sem encontrar saídas [...] acho que é essencial pro trabalho em saúde mental a gente ter se é viável ou não é outra situação mas que é fundamental [...] eu acho que a gente tenta assim eu percebo que a equipe tenta ter alguns espaços para socializar no sentido de às vezes não são nem espaços formais eu acho que as pessoas vão socializando suas angústias aonde vai dando assim no cotidiano né seja conversando com colega acho que as pessoas vão fazendo isso ou na reunião de equipe [...] mas realmente a gente não tem um mediador externo nesse papel de supervisor institucional que vá fazer esse papel mas espaço a gente tem pra falar alguma angústia talvez a gente não tenha isso sistematizado assim como uma supervisão [...] mas eu acho que a gente precisa de um espaço porque a gente percebe às vezes algumas pessoas adoecidas né olha fulano tá muito adoecido ali e aí fica uma situação meio constrangedora né de expor a pessoa de perceber que a pessoa aí pode virar uma coisa muito pessoal quando a gente traz pra reunião uma coisa que a gente observa no colega [...] quando a gente percebe que o adoecimento tá aqui na relação de trabalho aí é uma coisa muito delicada pra gente trazer né talvez num ambiente num setting mais protegido fica menos persecutório né uma pessoa de fora fazendo essa intermediação do que uma pessoa aqui do nosso convívio porque talvez a pessoa acabe levando pro lado pessoal. (GP)

A reivindicação do grupo de profissionais pela disponibilização de supervisão institucional foi justificada em razão de constituir-se como apoio pedagógico em relação aos questionamentos e dúvidas da equipe e, principalmente, como apoio terapêutico, em face da possibilidade de adoecimento dos trabalhadores. 
O grupo de interessados salientou, ainda, que a função de um supervisor institucional não caberia à própria equipe do serviço, sob pena de provocar constrangimentos entre os trabalhadores.

A preocupação trazida pelo grupo de profissionais acerca da necessidade de terem suas demandas pedagógicas e terapêuticas acolhidas sugere que o grupo almeja o desenvolvimento de suas capacidades. Essa preocupação está ligada à noção do fator Paidéia, na medida em que se dirige à construção de espaços coletivos que funcionem como dispositivos facilitadores para o desenvolvimento integral das pessoas ${ }^{(25,26)}$.

\subsection{Avaliação da satisfação e da percepção de mudança dos usuários}

Em função de apresentar identidade de sentidos, as construções compartilhadas que emergiram do grupo de usuários do CAPSad acerca da satisfação e da mudança percebida foram agrupadas em um mesmo núcleo temático, denominado neste estudo como "cuidado".

\subsubsection{Avaliação da satisfação dos usuários}

O tema "cuidado", no sentido do atendimento oferecido pelo CAPSad aos usuários, apresentou-se como central, tanto nas manifestações do grupo de usuários a respeito da satisfação, quanto acerca da mudança percebida.

Consoante os relatos a seguir, o grupo de usuários expressou de maneira consensual sua satisfação com o serviço do CAPSad:

Tô muito satisfeito às vezes eu que não satisfaço eles porque tem dia que dá vontade de tomar uma e pra quem é especialista só de olhar no seu rosto já sabe que você tomou uma mas eu tô fazendo o possível eu tô quase parando devido o tratamento que eles fazem aqui com a gente tem que valorizar [...] o tratamento que eles me dão aqui pra mim já é suficiente pra mim deixar o vício porque eu sou muito bem tratado aqui. (E1U)

O Caps tá me ajudando em muitas coisas porque tipo eu cheguei aqui muito depressivo não vou te falar que estou $100 \%$ não eles dão todas as ferramentas e o caminho pra gente seguir e o apoio vai da nossa determinação também seguir isso daí. (E2U)

Tô satisfeito com as pessoas que trabalham aqui. (E3U)

Tô satisfeito com o tratamento com as pessoas que trabalham aqui. (E6U)

Eu estou presentemente muito satisfeito embora nós devamos considerar a seguinte questão eu estive aqui no ano de 2015 dei início a um tratamento e 
não dei continuidade a esse tratamento mas o primeiro contato com esta unidade ali em 2015 foi um contato bastante positivo eu sempre tive um muito bom atendimento por parte dos profissionais naquela ocasião [...] atualmente 2017 eu retorno a esta unidade especificamente pelo fato de ter me sentido bem de ter sido bem atendido de ter tido uma boa impressão dos profissionais que fazem atendimento aqui [...] eu estou reforçando as primeiras impressões que são boas. (E7U)

Minha satisfação por enquanto eu não tenho o que reclamar não porque eu conheço o Caps desde 2002 e toda vez que eu fiz recuperação no Caps eu fiquei 10 anos sem usar drogas depois eu me afastei do Caps eu não vim mais nesse tempo eu não usei droga depois eu recaí e aí eu vi que não conseguia parar sozinho não fui internado em clínica nenhuma voltei de novo pra cá tô me sentindo bem desde março pra cá não tive mais problema com droga. $(\mathrm{E} 8 \mathrm{U})$

A satisfação e a percepção de mudanças, como salientado, foram referidas de maneira associada nas construções compartilhadas pelo grupo de usuários, podendo-se denotar, em virtude de alguns relatos, tratar-se de uma dinâmica de causa e efeito, na qual a satisfação aparece como consequência da percepção de mudanças positivas, conforme pode-se observar nas seguintes falas:

Tô satisfeito porque eu tenho visto mudança na minha vida [...] eu tenho achado bom o serviço [...] os profissionais sabem lidar com nós eles se preocupam em saber como a gente tá lidando então eu acho que o grupo ajuda bastante nesse lado aí de entender o usuário que sou eu [...] as atividades que eu tenho aqui melhora pra mim porque quando eu não tava na atividade aqui que eu tava na rua eu tava usando droga eu tava bebendo então as atividades de alguma forma elas me ajuda a esquecer um pouco o mundo lá fora entendeu eu com isso aí também vai me ajudando a diminuir o uso. (E5U)

Pra mim tem sido bom foi bom tem sido bom tanto é que eu já vou ter alta aqui e deu tudo certo tudo que eu esperava [...] pra mim foi tudo bom deu tudo certo não sei se com os outros usuários se é do mesmo jeito mas só sei que eu só tenho a agradecer mesmo que foi depois de tanto tempo que de um hospital a outro e lutando sozinha pra largar do álcool e nada de conseguir e cada vez me destruindo mais e aqui melhorei digamos assim $80 \%$ porque eu ainda tô em tratamento né. (E10U)

Acerca dessa associação entre satisfação e mudança percebida, estudo ${ }^{(31)}$ aponta que a percepção de mudanças positivas interfere na relação entre os resultados do tratamento e a satisfação dos usuários e que a ocorrência de mudanças objetivas (verificadas pelos profissionais), que não são efetivamente percebidas como positivas pelos usuários, não interferem na sua satisfação com o serviço.

O grupo salientou que se sente satisfeito com o acolhimento do serviço, sobretudo nos momentos tidos como difíceis de suas vidas, como nas situações de crise, nos problemas de 
relacionamento familiar, de desemprego, de situação de rua, de recaídas e nos momentos de uso constante de substâncias psicoativas, de acordo com os seguintes relatos:

Eu vim pro Caps porque eu não tinha lugar pra comer aí eu vim me falaram que tinha comida eu vim nesse pensativo mas só que hoje eu já não penso mais assim [...] depois que eu vim aqui comecei a conhecer o grupo comecei a ver que tava melhorando já mudou meu pensamento [...] eu vim aqui por uma decisão agora tô aqui por outra [...] eu até costumo comentar no grupo pra você fazer uma coisa você tem que gostar do que você faz e eu vejo aqui que as pessoas pelo menos as que trabalham neste Caps aqui eu vejo que as pessoas gostam do que faz porque eles cuidam entendeu tipo eles se preocupam com o usuário que sou eu então é bem bacana isso aí. (E5U)

Se você vai na casa de um parente vai te criticar vai reclamar aqui eles já acolhe a gente bem se preocupa como que a gente tá de saúde faz exame [...] você estando aqui dentro você tem a liberdade tem as atividades tem alimentação tem a descontração de poder assistir um filme tem acompanhamento do pessoal eles acolhem a gente parece que eles amam a gente até mais que a própria família que já se cansou mas mesmo assim eles não se cansa da gente tão ali tão lutando com a gente tão preocupado se preocupa até com a nossa aparência. (E2U)

Pra mim o Caps intercedeu na minha família [...] minha família fica bem contente quando eu venho no Caps entendeu fica bem contente comigo eles brigam comigo quando eu não venho. (GU)

Paralelamente à ênfase dada aos cuidados oferecidos pelo CAPSad, os usuários fizeram alusão à atenção recebida de seus próprios familiares e valeram-se dela como referência para considerar satisfatório o cuidado recebido no serviço. Essa aparente comparação feita pelo grupo de usuários entre as atitudes de seus familiares e a conduta dos profissionais do CAPSad pode expressar a relevância do vínculo estabelecido com o serviço, representado pelos usuários como da ordem de um convívio familiar.

Além de poder expressar a importância que o vínculo com o serviço tem para os usuários, a associação feita pelo grupo entre os cuidados de seus familiares e os cuidados oferecidos pelo serviço também pode caracterizar-se como uma maneira de os usuários estimarem sua satisfação, usando a experiência dos cuidados familiares como parâmetro para avaliar o serviço.

O grupo de usuários realçou, ainda, a compreensão e a resiliência dos profissionais do CAPSad nas situações de recaída dos usuários, de acordo com o seguinte relato:

Semana retrasada tive uma recaída mas não é culpa do Caps o culpado foi eu que fui atrás da droga então o pessoal aqui do Caps trata a gente muito bem pelo menos eu da minha parte não tenho o que reclamar do pessoal aqui [...] eles procuram tratar a gente pra gente não recair se recair eu retorno aqui que a gente tem apoio tem ajuda eles não abandonam a gente não é como muitos lugar que quando você recai você não é bem recebido. (E8U) 
O relato, ressaltando a atitude de acolhimento dos profissionais do CAPSad em face da ocorrência de recaídas, ilustra que os processos terapêuticos empregados no serviço são norteados pelas estratégias de redução de danos, conforme o estabelecido no Plano Emergencial de Ampliação do Acesso ao Tratamento e Prevenção em Álcool e outras Drogas no Sistema Único de Saúde ${ }^{(37)}$.

As estratégias de redução de danos estão dirigidas ao tratamento seguro em face dos comportamentos de risco e dos danos a eles associados. Essas estratégias pressupõem a ideia de que se vive em um mundo real (diverso de um mundo ideal), no qual são encontradas maneiras alternativas de reduzir prejuízos maiores, sempre levando-se em conta o respeito à liberdade de escolha dos usuários ${ }^{(38)}$.

Essa liberdade de escolha dos usuários, refletindo na sua corresponsabilização pelo tratamento, que compõe uma das balizas do paradigma da redução de danos (respeito aos direitos dos usuários), pode ser observada no seguinte relato:

ninguém me obrigou a vir aqui eu vim com as minhas próprias pernas porque pra mim não tava dando mais não chega cansei dessa vida pra mim não dá mais não aguento mais usar droga [...] se eu voltar a usar droga eu morro o médico já falou. (E8U)

\subsubsection{Avaliação da percepção de mudança dos usuários}

Com relação à mudança percebida, o grupo de usuários também expressou, de maneira compartilhada, a percepção de que o tratamento oferecido pelo CAPSad proporcionou mudanças positivas em suas vidas, de acordo com as seguintes falas:

Melhorou bastante porque eu cheguei aqui muito mal eu vim acompanhado pela minha família eles me acolheram eu já melhorei 80\%. (E1U)

Nota 10 eu já cheguei aqui passei por psicólogo passei por clínico fiz exame a orientação deles também isso muda quando a gente sai a gente sai com a cabeça mais fresca lá pra fora você pensa num objetivo diferente tanto que no tempo que eu tô aqui não tô tendo problema com álcool nem com no meu caso também era a cocaína [...] já me senti diferente porque senão numa hora desta se eu não tivesse aqui com certeza eu já taria bêbado e hoje em dia eu já penso diferente qual é o meu foco de ajuntar de fazer uma renda fixa por mês pra pelo menos arrumar uma pensão e sair do albergue. (E2U)

Mudou mudou minha inteligência já desintoxicou bem eu não conseguia dormir eu tinha pesadelo por causa da droga eu tinha pressentimento que alguém ia me matar entendeu hoje eu melhorei bastante. (E3U) 
Mudou porque eu escutei a história das pessoas que frequentam então eu falei toma vergonha na cara para com esse baseado aí cara entendeu. (E4U)

Eu sou dependente químico e também sou alcoólatra e eu tipo eu não tinha controle não vou dizer pra você que eu parei mas hoje eu já tenho um controle umas história que aqui com os profissionais eles tipo de alguma forma nos ajuda porque antes eu não tinha controle hoje eu consigo ter um controle tipo assim antes eu botava mil reais no bolso no outro dia chegava sem nenhum centavo na mão e hoje em dia eu já tenho esse controle [...] eu percebi mudança sim porque antes eu só pensava no uso da droga e hoje eu tenho outros pensamentos eu penso em voltar a trabalhar arrumar um emprego que você não sabe eu moro na rua eu dependo de um serviço social aí pra dormir e tipo hoje eu já tenho outros pensamentos construtivos [...] que antes eu não tinha né. (E5U)

É perceptível a mudança de comportamento até porque eu tenho alguma experiência com profissionais desta área da saúde o meu histórico pessoal com relação ao consumo de álcool e eventualmente de outra droga no caso cocaína já foi objeto de tratamento em outras instituições e com outros profissionais inclusive de cunho particular então toda vez e principalmente neste momento em que eu me predisponho a iniciar um tratamento. (E7U)

Meu uso era diário dei uma reduzida né porque eu tive aquele estalar de acordar junto com as atividades que eu já passei aqui e o Acompanhamento médico eu consegui acordar pra vida mesmo porque quando a gente tá no uso constante né a gente entra assim num mundo de escuridão falando por min né eu tava num uso diário então eu creio que eu tive resultado né bem significativo [...] percebi uma grande diferença já não estou no uso constante. (E9U)

Minha vida mudou muito antes eu bebia muito eu bebia bastante eu perdia o controle e agora não e nem tem muito tempo que eu tô aqui eles me ajudaram muito. (E10U)

Eu melhorei $[\ldots]$ no meu caso também [...] eu melhorei bastante. (GU)

Como observado nos relatos, o grupo de usuários percebeu a ocorrência de mudanças benéficas em suas vidas com o tratamento realizado no CAPSad. As mudanças apontadas pelos usuários referiram-se, principalmente, ao próprio uso de substâncias psicoativas e em torno da organização de suas vidas de modo geral.

O grupo de usuários relatou que as mudanças positivas também foram percebidas e valorizadas pelos seus familiares e pelas demais pessoas com as quais os usuários convivem, conforme as seguintes falas:

Eu tava mais envolvido em drogas hoje eu já diminui bastante com a ajuda deles com remédio to melhorando aí faço meu tratamento já consegui voltar a trabalhar [...] fazia 13 anos que eu não falava com as minhas filhas foi onde eu conversei com elas [..] eu pedi ajuda pra referência pedi pra ela ligar pra eu conversar com minhas filhas aí minha ex-mulher aceitou eu poder falar com as minhas filhas. (E6U) 
A mudança do comportamento é visível é sentida por mim e visível pelo meu círculo social quer seja a família mais próxima quer seja o círculo familiar parentesco um pouquinho mais distante ambiente de trabalho ambiente acadêmico e ambiente social em geral. (E7U)

Bastante mudança meu comportamento em casa mudou muito antigamente eu chegava em casa ignorando todo mundo eu queria quebrar as coisas dentro de casa então graças à ajuda que eu tive dos profissionais igual eu tava te falando mudou muita coisa na minha vida a minha família tá contente comigo de eu tá vindo aqui de eu ter procurado ajuda sozinho. (E8U)

Além da percepção da ocorrência de mudanças relativas ao próprio uso de substâncias psicoativas e em torno da organização de suas vidas, o grupo de usuários fez referências a ocorrência de reforço ou de restabelecimento de seus laços familiares, atribuindo a consecução desses resultados ao tratamento e ao trabalho de mediação feito pelo CAPSad.

As construções formuladas pelo grupo de usuários - acerca das mudanças favoráveis percebidas em suas vidas como resultado do tratamento realizado no CAPSad - indicam que o serviço trabalha em favor do desenvolvimento dos usuários, operando no sentido do fator Paidéia. O serviço trabalha com vistas à coprodução de sujeitos autônomos, uma vez que, para o método da Roda, a clínica, a saúde pública e a gestão produzem modos de ser (subjetividades) e a produção de valores de uso tem o potencial para constituir pessoas dependentes ou autônomas.

No caso do presente grupo de usuários, as mudanças relatadas são atinentes à produção de autonomia, de ampliação da capacidade de análise e de intervenção na sua própria realidade $^{(25,26)}$.

\subsection{Avaliação da satisfação e da percepção de mudança dos familiares}

As construções compartilhadas pelo grupo de familiares a respeito da satisfação e da percepção de mudança também apresentaram identidade de sentidos, tendo sido condensadas em um único núcleo temático, denominado de "cuidado".

\subsubsection{Avaliação da satisfação dos familiares}

O núcleo temático "cuidado", assim como observado no grupo de usuários, envolveu os aspectos da assistência oferecida pelo CAPSad, tendo sido tema recorrente nas construções compartilhadas pelo grupo de familiares acerca tanto da satisfação, quanto da percepção de 
mudanças. O grupo de familiares assentou consensualmente que está satisfeito com o CAPSad, conforme verifica-se nas seguintes falas:

Minha satisfação é ótima porque eu estou contente com o trabalho deles. (E2F)

Quando eu tô eu vejo aqui que são todos muito bem atendidos e não vejo assim faltar nada chega gente aqui é o lanche e às vezes até fora de hora eles dá o lanchinho pra aquele que tá assim agitado. (E2F)

Estou satisfeita porque eu vejo que o esforço deles é grande agora é o paciente que não corresponde eles são muito amorosos aqui viu todos eles mesmo que troquem eles são muito atenciosos todos sem exceção me atendem muito bem a hora que eu chego aqui eles me atendem. (E3F)

Atende com muita atenção muita paciência muito bom. (E4F)

Daqui do CAPSad eu não tenho o que me queixar. (E5F)

Satisfeita porque embora faz pouco tempo que eu faço atendimento aqui né mas até aqui eu tenho gostado tudo ok. (E6F)

Como observado, o grupo de familiares expressou sua satisfação com o CAPSad no sentido de sentir-se acolhido pelo serviço, que foi considerado pelo grupo como um espaço de escuta, no qual os familiares se sentem atendidos pela equipe de profissionais, que é vista como disponível para ouvi-los, de acordo com a seguinte fala:

Tem me ajudado muito porque devido a esses problemas que a gente vem enfrentando familiar então é muito importante você estar interagindo com outras pessoas que possa te entender que possa te ouvir né então é os princípios daqui é isso deles ouvir ouvir o que você tem pra dizer porque nem sempre lá fora tem alguém que tá disposto a ouvir o que você tem pra falar [...] cada um pega aborda o assunto de cada um né e nós vamos discutindo cada um vai dando sua opinião vai ouvindo o assunto de cada um cada problema de cada um e assim a gente vai ajuda a nós a desenvolver também no lar aquele problema que a gente tá passando. (E6F)

$\mathrm{O}$ atendimento à família constitui-se como uma das atribuições do CAPSad, de acordo com a portaria ministerial que rege suas competências ${ }^{(12)}$. A inclusão dos familiares do paciente nos atendimentos se deve ao fato de que o sofrimento psíquico decorrente do uso de substâncias psicoativas não se restringe à pessoa do paciente, envolvendo também sua esfera social, particularmente, seu círculo familiar, que precisa se reorganizar em razão do convívio diário com o paciente e com a eventual assunção da função de cuidador do paciente, em colaboração com o serviço.

Ainda com relação à satisfação, o grupo de familiares atribuiu às orientações que recebe da equipe de profissionais nos atendimentos de que participa como mais um determinante positivo para sua satisfação com o CAPSad, de acordo com as seguintes asserções: 
É bom, melhora bastante eles orientam a gente pra estar lidando com eles. (E1F)

Satisfeita sim porque ele me orientou ele me orienta né os profissionais daqui me orienta pra mim ter uma resolução pra mim me alivia a vida pra mim ter uma orientação tudo é orientação de como você conviver com uma pessoa que depende dos vícios álcool que seja cigarro e tudo eu acho que tá sim pra mim e também pras pessoas que vêm junto também tá ótimo [...] pra mim lidar eu acho que eu sei como conversar com ele da minha parte pra ele como lidar com essa situação a gente vem pra uma orientação pra orientar a gente era muito agressivo um com o outro porque a gente gritava palavras conflitos isso já mudou um pouco não totalmente e aí eu quero uma mudança dele mudar internamente eu sei eu entendo que tem que ter muita conversa muito mais entendimento ainda. (E4F)

A partir do momento em que eu comecei a frequentar aqui eu me senti bem mais forte porque eu sabia que eu tinha um apoio ali né eu vim mesmo mais desanimada meu neto tinha sido internado muitas vezes e a gente achava que não havia solução que não adiantava internação. (EF5)

Sim pra mim sim ele não porque ele não se interessa em mudar mas a mim sim pra mim foi uma ajuda porque só de eu tá desabafando o que eu passo dentro do lar pra mim é um alívio muito grande só de ter uma pessoa pra ouvir o que eu tenho pra dizer é um alivio muito grande é uma ajuda pra mim é muito importante pra mim tá desabafando porque toda semana todos os dias pra mim é um desafio sempre tem problemas novos pra falar pra debater entendeu então pra mim desabafar tudo isso pra mim é um alívio muito grande. (E6F)

Sim porque você tem uma informação [...] pra mim foi bem melhor eu fiquei mais light ainda [...] eu também [...] o meu marido percebe em mim que tudo eu levo mais light e alguma coisa que ele falava eu não concordava mas eu não sabia falar e hoje não ele percebe em mim que eu fico mais calma converso com ele melhor sobre o assunto e ele também tá mais calmo. (GF)

Com efeito, o grupo de familiares considerou, basicamente, estar satisfeito com o CAPSad em razão do serviço lhes proporcionar um espaço de escuta de suas demandas e lhes oferecer orientações gerais para lidar com os pacientes. Essas funções pedagógicas e terapêuticas narradas pelo grupo de familiares no CAPSad contribuem para a promoção de sua autonomia (fator Paidéia), ampliando sua capacidade de análise e de intervenção.

\subsubsection{Avaliação da percepção de mudança dos familiares}

Com relação à percepção de mudanças ocorridas na vida dos pacientes atendidos no serviço, com exceção de uma das participantes do grupo de familiares, as demais participantes do grupo relataram que perceberam mudanças positivas na vida dos pacientes como resultados do tratamento prestado pelo CAPSad, conforme os seguintes relatos: 
Ele melhorou bastante porque antigamente ele andava pela rua ficava igual mendigo carregando lixo para dentro de casa era um caos teve vez de eu tirar era caminhão de lixo da casa dele era lixo que não prestava, até fralda descartável, qualquer porcaria ele trazia para dentro de casa. (E1F)

Ela chegou muito ruim, mas muito ruim mesmo assim é de duas pessoas eu e meu compadre que trouxe ela quer dizer carregada né chegou muito mal e graças a Deus hoje ela tá mais não vou falar que ela tá curada porque ela não sarou ainda porque ainda ela tá tomando né mas ela tá bem [...] percebi percebi percebi mudanças sim boas mudanças eu sinto assim que não foi mais não foi problema deles não é dela mesma faltou em consulta eu chegava na casa dela ela falava hoje eu não vou não tô com vontade de ir sabe porque eu acho assim começou um tratamento tem que ir até o fim né. (E2F)

Quando ele começa a participar aqui vir a gente percebe ele fica outro sabe agora quando ele não aparece quando ele está na rua mesmo nas drogas ou na bebida ele muda né aí ele não vem ele só vem quando ele está melhorzinho [...] mudanças positivas positivas porque quando ele participa aqui que eu sei que ele tá vindo todo dia aqui é porque ele tá bem porque quando ele não tá bem ele não aparece. (E5F)

Como observado nas falas, as participantes do grupo de familiares, que perceberam mudanças positivas na vida dos pacientes, relataram a percepção de mudanças de natureza comportamental dos pacientes, particularmente relacionadas ao consumo de substâncias psicoativas.

Ao mesmo tempo em que relataram as mudanças percebidas, o grupo de familiares esclareceu que as mudanças dependem da adesão dos pacientes ao tratamento no CAPSad, transmitindo a ideia de que havia potencial de mudanças que não foi atingido devido à ocorrência de descontinuidade do tratamento, em função da ausência dos pacientes nos atendimentos do serviço.

A participante do grupo de familiares, que relatou não haver percebido mudanças positivas na vida do paciente, justificou essa inobservância pelo quadro de deficiência mental do paciente, de acordo com a seguintes fala:

Ele não melhorou porque ele tem problema mental também eu sei que é três problemas que ele tem grave de cabeça não consegue aprender é retraído tem dificuldade de fazer amizade com as pessoas tudo ele fala que não gosta porque ele começou esse vício com 25 anos. (E3F)

O paciente referido pela participante do grupo de familiares como aquele em que não se percebeu mudanças com o tratamento, no momento da coleta de dados do presente estudo, encontrava-se internado em comunidade terapêutica.

Conforme observações de campo realizadas nas reuniões de grupo de famílias, o paciente em questão fora internado por iniciativa de seus próprios familiares, à revelia da equipe 
do CAPSad. Ainda segundo as observações, a internação ocorreu de maneira involuntária, sem a anuência do paciente, o qual, até então, era atendido pelo serviço.

Com efeito, o grupo de familiares não entrou em consenso com relação às construções acerca da mudança percebida na vida dos pacientes como resultado do tratamento.

A divergência apresentada pela inobservância de mudanças motivou, ao menos em parte, a busca por outra modalidade de tratamento, qual seja, a internação involuntária do paciente em comunidade terapêutica, que se processou sem a participação do CAPSad.

Embora não tenha havido consenso por parte do grupo de familiares a respeito das mudanças percebidas na vida dos pacientes, as observações de campo registraram que o grupo de familiares prosseguiu comparecendo às reuniões de família oferecidas pelo serviço, indicando que o CAPSad disponibiliza de espaços coletivos, os quais têm o objetivo de assegurar aos interessados a possiblidade concreta, de tempo e lugar, de analisar suas próprias dificuldades e de tomar decisões sobre elas.

O dissenso acerca da percepção de mudanças por parte do grupo de familiares também indicou que esses mesmos espaços coletivos oferecidos pelo CAPSad podem ser ocupados por pessoas que, embora tenham identidade de interesses (a saúde dos pacientes), defendem valores diversos (modelos de tratamento), que são respeitados e discutidos de forma democrática. Constituindo-se, portanto, como rodas, no sentido apregoado pelo método da Roda, ou seja, espaços coletivos dirigidos para a ampliação da capacidade de análise e de intervenção das pessoas e dos coletivos sobre suas realidades ${ }^{(25,26)}$. 
7 CONCLUSÕES 


\section{CONCLUSÕES}

Concluiu-se que a presente pesquisa alcançou os objetivos propostos, mediante a aplicação ética da metodologia cominada.

O campo de estudo, CAPSad 3, foi identificado por meio da classificação dos valores das medianas observadas no banco de dados do GEAD.

O estudo da satisfação dos profissionais do CAPSad 3, a partir das construções que emergiram de seu grupo de interesses, revelou diversos fatores que a modulam simultaneamente, seja para promovê-la, seja para arrefecê-la.

Os fatores que convergiram para a promoção da satisfação dos profissionais envolveram alguns aspectos e características da prática assistencial empreendida no serviço. Por outro lado, fatores relacionados à própria prática assistencial, além de outros atinentes à gestão do serviço e à educação permanente, conjugaram-se de modo a desfavorecer a satisfação dos profissionais.

Os fatores que promoveram a satisfação dos profissionais referiram-se à realização das atividades ordinárias do serviço, notadamente àquelas nas quais os profissionais percebem a ocorrência de mudanças positivas na vida dos usuários. Também contribuiu para a satisfação dos profissionais, a dinâmica multidisciplinar da equipe de trabalho, no sentido da possibilidade de troca de experiências entre os profissionais. Ainda no âmbito da assistência, influenciou positivamente a satisfação dos profissionais a condição de poderem participar ativamente da construção da clínica do serviço, entendida como em processo de desenvolvimento.

Com relação aos fatores que não favoreceram a satisfação dos profissionais, no campo da assistência emergiu a questão dos efeitos do trabalho de longo prazo no atendimento aos usuários. $\mathrm{O}$ grupo de interesses relatou que a complexidade de lidar continuamente e por longos períodos com as demandas dos usuários não contribui para a satisfação dos profissionais, podendo ocasionar, inclusive, sensação de esgotamento nos trabalhadores.

No domínio da gestão do serviço, de acordo com o grupo de interesses, os profissionais consideraram que o cumprimento das metas do serviço, estabelecidas à sua revelia, não favorece a satisfação dos trabalhadores em razão da sensação de esgotamento, desconforto, ansiedade e angústia, resultantes das cobranças e pressões para o cumprimento das metas. $\mathrm{O}$ grupo também expressou sua insatisfação com as metas do serviço ao relatar que as percebem como prejudiciais à própria qualidade da assistência prestada pelo serviço, em função de as considerar como meros instrumentos de burocratização da organização do CAPSad. 
$\mathrm{Na}$ esfera do ensino, o grupo de profissionais apontou que a carência de investimentos por parte da gestão do serviço no desenvolvimento da educação permanente dos trabalhadores não favorece a satisfação. Além do apoio pedagógico, o grupo também ressaltou a carência de suporte terapêutico para os próprios profissionais.

$\mathrm{Na}$ etapa de negociação do processo avaliativo, o grupo de profissionais estabeleceu consensos acerca das construções relativas à suas preocupações, reivindicações e questões.

Em relação à preocupação de sofrer esgotamento em decorrência de trabalhar diretamente e por períodos de longo prazo com as demandas dos usuários, o grupo de profissionais consentiu que o compartilhamento dos atendimentos entre os membros da equipe pode diminuir as possibilidades de esgotamento, porquanto, evitariam o que o próprio grupo denominou de "personalização" dos atendimentos, consistente na centralização dos cuidados do usuário na pessoa de determinado profissional, a despeito do modelo multidisciplinar adotado pelo serviço.

A negociação em face da questão das metas impostas pelo serviço, conduziu o grupo de profissionais ao consenso de reivindicar o direito de participação na concepção das metas do serviço, uma vez em que, no atual modelo de gestão, os trabalhadores não detêm governabilidade sobre o estabelecimento das metas.

Ainda na fase de negociação, o grupo de interesses, compartilhando sua preocupação com a necessidade de apoio pedagógico-terapêutico, reivindicou a contratação de supervisão institucional, justificando-a como imprescindível, em se tratando de serviço de saúde mental.

A avaliação da satisfação e da percepção de mudança dos usuários do serviço apresentou certa relação de causa e efeito, na medida em que alguns relatos acerca da satisfação aduziam a mudanças decorrentes do tratamento no CAPSad.

A respeito da satisfação dos usuários, seu grupo de interesses manifestou-se, consensualmente, no sentido de que se sente satisfeito com o atendimento oferecido pelo serviço, dando destaque à qualidade do acolhimento disponibilizado pelo CAPSad. Tratando da percepção de mudança, o grupo de usuários reconheceu, também de maneira consensual que percebeu mudanças positivas em suas vidas como resultados do tratamento recebido no serviço, enfatizando mudanças relativas ao uso de substâncias psicoativas, à organização de suas vidas e em relação aos seus laços familiares.

Acerca da avaliação da satisfação e da percepção de mudança dos familiares, houve consenso do grupo de implicados em relação à satisfação - considerada positiva, e dissenso em face da percepção de mudanças observadas na vida dos pacientes. 
O grupo de familiares compartilhou o entendimento de que está satisfeito com o CAPSad, particularmente, em virtude de o serviço proporcionar aos familiares espaço de escuta e, ao mesmo tempo, oferecer-lhes orientações gerais para compreender e lidar com os pacientes. Já com relação à percepção de mudança, o grupo de familiares não estabeleceu um consenso. Os familiares que perceberam mudanças positivas na vida dos pacientes em função do tratamento no CAPSad mencionaram a ocorrência de mudanças de natureza comportamental dos pacientes, sobretudo relacionadas ao consumo de substâncias psicoativas. O familiar que não percebeu mudanças na vida do paciente o encaminhou para outra modalidade de tratamento, qual seja, internação involuntária do paciente. 
8 CONSIDERACÕES FINAIS 


\section{CONSIDERAÇÕES FINAIS}

O presente estudo não tratou de concluir se os grupos de interesses estavam ou não satisfeitos, mas sim de apresentar, na perspectiva desses grupos, as representações subjacentes à satisfação. Ou seja, a pesquisa buscou apreender os significados, os valores, as crenças, as atitudes e as aspirações dos interessados acerca da satisfação. A satisfação, portanto, vista como resultante de um processo permeado pelas contingências relatadas pelos implicados, as quais, mesmo que antagônicas, concorrem, coexistem e coincidem sobre eles. Nesse mister, a pesquisa logrou compilar as representações que refletiram os sentidos da satisfação pelos grupos. Isso em decorrência da participação efetivamente construtiva dos três grupos de interesses na pesquisa.

A divergência apontada pelo grupo de familiares acerca da percepção de mudanças pode representar um dos desafios do serviço. Não obstante, também pode evidenciar a abertura do serviço à diversidade de opiniões da comunidade e, ao mesmo tempo, reafirmar o seu papel na assistência em saúde mental em álcool e outras drogas.

O método da pesquisa revelou-se adequado, principalmente, por propiciar aos grupos de implicados a oportunidade de negociarem, de maneira democrática, suas próprias reivindicações, preocupações e questões, em um ambiente participativo.

Em relação às limitações da pesquisa, ressalta-se que a realização de todas as atividades, com todos os grupos de interesses, por um único pesquisador pode influenciar, em algum grau, o nível de qualidade do trabalho desenvolvido no campo de pesquisa, na medida em que o método, exigindo que a coleta e a análise dos dados ocorram em um processo sucessivo e constante, demanda um ritmo de trabalho intenso, de modo que se sugere que pesquisas similares sejam empreendidas por uma equipe de pesquisadores, com vistas à maximizar a qualidade do trabalho de campo. 
REFERENNCIAS 


\section{REFERÊNCIAS}

1. WHO. Global status report on alcohol and health 2014. Geneva: World Health Organization; 2014.

2. WHO. Raising tax on tobacco: what you need to know. Geneva: World Health Organization; 2014.

3. UNODC. World Drug report 2014. New York: United Nations; 2014.

4. Laranjeira R. Segundo Levantamento Nacional de Álcool e Drogas. São Paulo: Instituto Nacional de Ciência e Tecnologia para Políticas Públicas de Álcool e Outras Drogas (INPAD), UNIFESP.; 2012.

5. Fundação Oswaldo Cruz. Ministério da Saúde. Secretaria Nacional de Políticas sobre Drogas. Ministério da Justiça. Estimativa do número de usuários de crack e/ou similares nas capitais do país. Rio de Janeiro: FIOCRUZ; 2013. Disponível em: http://img.medscape.com/images/6501252/6501252-perfilusuarios.pdf.

6. Brasil. Lei n. 10216, de 6 de abril de 2001. Dispõe sobre a proteção e os direitos das pessoas portadoras de transtornos mentais e redireciona o modelo assistencial em saúde mental: Diário Oficial da União, Brasília, 9 abr. 2001. Disponível em: http://www.planalto.gov.br/ccivil_03/leis/leis_2001/110216.htm.

7. Brasil. Lei n. 11.343, de 23 de agosto de 2006. Institui o Sistema Nacional de Políticas Públicas sobre Drogas - Sisnad; prescreve medidas para prevenção do uso indevido, atenção e reinserção social de usuários e dependentes de drogas; estabelece normas para repressão à produção não autorizada e ao tráfico ilícito de drogas; define crimes e dá outras providências. Diário Oficial da União, Brasília, 24 ago. 2006. Disponível em: http://www.planalto.gov.br/ccivil_03/_ato2004-2006/2006/lei/111343.htm

8. Conselho Nacional Antidrogas. Resolução n. 03, de 27 de outrubro de 2005. Diário Oficial da União, Brasília, 28 out. 2005. Disponível em: https://www.legisweb.com.br/legislacao/?id=101642

9. Brasil. Decreto n. 6177, de 22 de maio de 2007. Aprova a Política Nacional sobre o Álcool, dispõe sobre as medidas para redução do uso indevido de álcool e sua associação com a violência e criminalidade, e dá outras providências. Diário Oficial da União, Brasília, 23 mai. 2007.

10. Brasil. Decreto n. 7179, de 20 de maio de 2010. Institui o Plano Integrado de Enfrentamento ao Crack e outras Drogas, cria o seu Comitê Gestor, e dá outras 
providências. Diário Oficial da União, Brasília, 21 mai. 2010. Disponível em: http://www.planalto.gov.br/ccivil_03/_ato2007-2010/2010/decreto/d7179.htm

11. Brasil. Lei n. 8080, de 19 de setembro de 1990. Dispõe sobre as condições para a promoção, proteção e recuperação da saúde, a organização e o funcionamento dos serviços correspondentes e dá outras providências. Diário Oficial da União, Brasília, 20 set. 1990. Disponível em: http://www.planalto.gov.br/ccivil_03/leis/18080.htm.

12. Brasil. Ministério da Saúde. Portaria n. 336, de 19 de fevereiro de 2002. Diário Oficial da União, Brasília, 20 fev. $2002 . \quad$ Disponível em: http://bvsms.saude.gov.br/bvs/saudelegis/gm/2002/prt0336_19_02_2002.html.

13. Fundação Oswaldo Cruz. Ministério da Saúde. Secretaria Nacional de Políticas sobre Drogas. Ministério da Justiça. Perfil dos usuários de crack e/ou similares no Brasil. Rio de Janeiro: FIOCRUZ; 2013. Disponível em: http://portal.fiocruz.br/pt-br/content/maiorpesquisa-sobre-crack-j\%C3\%A1-feita-no-mundo-mostra-o-perfil-do-consumo-no-brasil.

14. Brasil. Emenda Constitucional n. 19, de 04 de junho de 1998. Modifica o regime e dispõe sobre princípios e normas da Administração Pública, servidores e agentes políticos, controle de despesas e finanças públicas e custeio de atividades a cargo do Distrito Federal, e dá outras providências. Diário Oficial da União, Brasília, 5 jun. 1998. Disponível em: http://www.planalto.gov.br/ccivil_03/constituicao/Emendas/Emc/emc19.htm.

15. Brasil. Ministério da Saúde. Programa Nacional de Avaliação de Serviços de Saúde: Resultado do processo avaliativo 2004-2006. Brasília: Ministério da Saúde; 2007. Disponível em: http://www.anvisa.gov.br/servicosaude/manuais/pnass.pdf.

16. Deslandes SF. Concepções em pesquisa social: articulações com o campo da avaliação em serviços de saúde. Cad Saúde Pública. 1997;13(1):103-7.

17. Barbosa GC. Avaliação do Centro de Atenção Psicossocial em Álcool e Outras Drogas do Município de Botucatu [tese]. São Paulo: Escola de Enfermagem, Universidade de São Paulo; 2013.

18. Pinho PH. Avaliação dos Centros de Atenção Psicossocial em Álcool e Outras Drogas do Município de São Paulo. São Paulo. [tese]. São Paulo: Escola de Enfermagem, Universidade de São Paulo; 2014.

19. Gonçalves RMDA. Avaliação dos Centros de Atenção Psicossocial em Álcool e outras Drogas do Estado de Minas Gerais [tese]. São Paulo: Escola de Enfermagem, Universidade de São Paulo; 2016. 
20. Prates JG. Avaliação das atitudes dos profissionais de Centros de Atenção Psicossocial em Álcool e outras Drogas do município de São Paulo [tese]. São Paulo: Escola de Enfermagem , Universidade de São Paulo; 2016.

21. Minayo MCS, organizadora. Pesquisa social: teoria, método e criatividade. 27 ed. Petrópolis: Vozes; 2008.

22. Minayo MCS. Amostragem e saturação em pesquisa qualitativa: consensos e controvérsias. Revista Pesquisa Qualitativa. 2017;5(7):1-12.

23. Wetzel C. Avaliação de serviço em saúde mental: a construção de um processo participativo. [tese] Ribeirão Preto: Escola de Enfermagem de Ribeirão Preto, Universidade de São Paulo; 2005.

24. Guba EG, Lincoln YS. Avaliação de quarta geração. Campinas: Unicamp; 2011.

25. Campos GWS. Um método para análise e co-gestão de coletivos: a constituição do sujeito, a produção de valor de uso e a democracia em instituições: o método da roda. 2 ed. São Paulo: Hucitec; 2005.

26. Campos GWS. Saúde Paidéia. 2 ed. São Paulo: Hucitec; 2005.

27. Furtado JP. Um método construtivista para a avaliação em saúde. Cien Saude Colet. 2001;6(1):165-81.

28. Lüdke M, André MEDA. Pesquisa em educação: abordagens qualitativas. São Paulo: EPU; 1986.

29. Ferreira ABH. Dicionário Aurélio da língua portuguesa. 5 ed. Curitiba: Positivo; 2010.

30. Esperidião MA, Trad LAB. Avaliação de satisfação de usuários: considerações teóricoconceituais. Cad Saúde Pública. 2006;22(6):1267-76.

31. Bandeira MB, Andrade MCR, Costa CS, Silva MA. Percepção dos pacientes sobre o tratamento em serviços de saúde mental: validação da escala de mudança percebida. Psicologia: Reflexão e Crítica. 2011;24(2):236-43.

32. Cesari L, Bandeira M. Assessment of quality of life and perception of change in patients with schizophrenia. J Bras Psiquiatr. 2010;59(4):293-301. 
33. Bandeira M, Felicio CM, Cesari L. Validação da escala de percepção de mudanças pelos familiares como medida de resultado do tratamento em serviços de saúde mental. Rev Bras Psiquiatr. 2010;32(3):283-7.

34. Brasil. Ministério da Saúde. Conselho Nacional de Saúde. Resolução n. 466 de 12 de dezembro de 2012. Diário Oficial da União, Brasília, 13 jun. 2013.

35. Bandeira M, Pitta AMF, Mercier C. Escalas brasileiras de avaliação de satisfação (SATISBR) e da sobrecarga (IMPACTO-BR) da equipe técnica em serviços de saúde mental. J Bras Psiquiatr 49(4):105-15.

36. Crespo AA. Estatística fácil. 18a ed. São Paulo: Saraiva; 2004.

37. Brasil. Ministério da Saúde. Portaria n. 1190, de 04 de junho de 2009. Institui o Plano Emergencial de Ampliação do Acesso ao Tratamento e Prevenção em Álcool e outras Drogas no Sistema Único de Saúde - SUS (PEAD 2009-2010) e define suas diretrizes gerais, ações e metas. Diário Oficial da União, Brasília, 5 jun. 2009.

38. Queiroz IS. Os programas de redução de danos como espaços de exercício da cidadania dos usuários de drogas. Psicol cienc prof. 2001;21(4):2-15. 
APÊNDICE 


\section{APÊNDICE}

APÊNDICE A - Termo de Consentimento Livre e Esclarecido

Convido o (a) Sr (a) a participar da pesquisa intitulada "Avaliação participativa de um serviço de atenção psicossocial em álcool e outras drogas”, desenvolvida por mim, Ricardo Henrique Soares.

A pesquisa pode contribuir para melhorar a qualidade do serviço prestado pelos Centros de Atenção Psicossocial Álcool e Drogas (CAPSad), ao levantarmos as necessidades e os pontos que devem ser melhorados no serviço para melhor atender à população.

A pesquisa tem o objetivo de verificar se os usuários, familiares e profissionais do CAPSad estão satisfeitos com o serviço oferecido e também verificar se os usuários e familiares atendidos pelo CAPSad perceberam mudanças nas suas vidas com o tratamento oferecido pelo CAPSad.

Se o (a) Sr (a) aceitar participar da pesquisa, nós faremos 02 encontros no próprio CAPSad. No primeiro encontro, faremos uma entrevista individual, com duração de aproximadamente 1 hora, onde eu farei perguntas sobre o atendimento no CAPSad. No segundo encontro, faremos uma entrevista em grupo, com duração de aproximadamente 2 horas, onde eu farei perguntas sobre alguns pontos discutidos nas entrevistas individuais, esclarecendo que durante a entrevista em grupo ninguém saberá quais foram as respostas que o (a) Sr (a) deu na entrevista individual.

As respostas do (a) Sr (a) serão identificadas por um número e seu nome e sua identidade não serão divulgados em nenhum momento e em nenhuma publicação.

Se o (a) Sr. (a) autorizar, eu gostaria de gravar suas respostas durante as entrevistas, esclarecendo que depois que eu transcrever suas respostas, todas as gravações serão deletadas.

Existe o risco do (a) $\mathrm{Sr}$ (a) se sentir desconfortável ao participar da pesquisa porque as entrevistas podem ser longas e as perguntas podem incomodar o (a) $\mathrm{Sr}$ (a). Por essa razão, se o (a) Sr (a) se sentir desconfortável, as entrevistas serão interrompidas imediatamente e se for necessário o (a) Sr (a) será encaminhado para atendimento.

O (a) Sr. (a) poderá se recusar a participar ou abandonar sua participação na pesquisa a qualquer momento e isto não lhe causará nenhum problema ou prejuízo, inclusive quanto ao seu atendimento no CAPSad. 
A pesquisa terá o benefício de levar informações importantes aos responsáveis pelos CAPSad e à sociedade em geral sobre os pontos que devem ser melhorados no serviço para atender melhor a população.

Após a leitura, este Termo de Consentimento Livre e Esclarecido deve ser rubricado pelo (a) $\mathrm{Sr}$ (a) em todas as páginas e assinado nas duas vias.

O (a) Sr (a) receberá uma via deste Termo de Consentimento Livre e Esclarecido, também rubricado e assinado por mim.

$\mathrm{O}$ (a) Sr (a) não terá nenhuma despesa ao participar da pesquisa e não receberá nada por participar da pesquisa.

Se o (a) Sr (a) sofrer algum problema por causa da pesquisa, eu serei responsável em reparar o problema e indenizá-lo (a), pois eu sou responsável por todas as consequências da pesquisa.

Se o (a) Sr (a) tiver alguma dúvida sobre a ética desta pesquisa, entre em contato com os Comitês de Ética em Pesquisa da Escola de Enfermagem da Universidade de São Paulo e da Secretaria Municipal de Saúde do Município de São Paulo, pelos seguintes contatos:

- Comitê de Ética em Pesquisa da Escola de Enfermagem da Universidade de São Paulo (CEP-EEUSP). Endereço: Av. Dr. Enéas de Carvalho Aguiar, 419, Cerqueira Cesar, São Paulo/SP, CEP 05403-000. Telefone (11) 30618858 - e-mail cepee@usp.br

- Comitê de Ética em Pesquisa da Secretaria Municipal de Saúde do Município de São Paulo (CEP/SMS-SP). Endereço: Rua General Jardim, 36, $8^{\circ}$ andar, Vila Buarque, CEP 01223010, São Paulo/SP. Telefone (11) 3397-2464 - e-mail smscep@gmail.com

Esta pesquisa atende a todas as especificações da Resolução 466, de 12 de dezembro de 2012 que aprova as diretrizes e normas regulamentadoras de pesquisas envolvendo seres humanos.

Assinatura do pesquisador

Assinatura do participante

Data

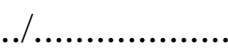


ANEXOS 


\section{ANEXOS}

ANEXO A - Parecer de Aprovação do Comitê de Ética em Pesquisa da Escola de Enfermagem da Universidade de São Paulo

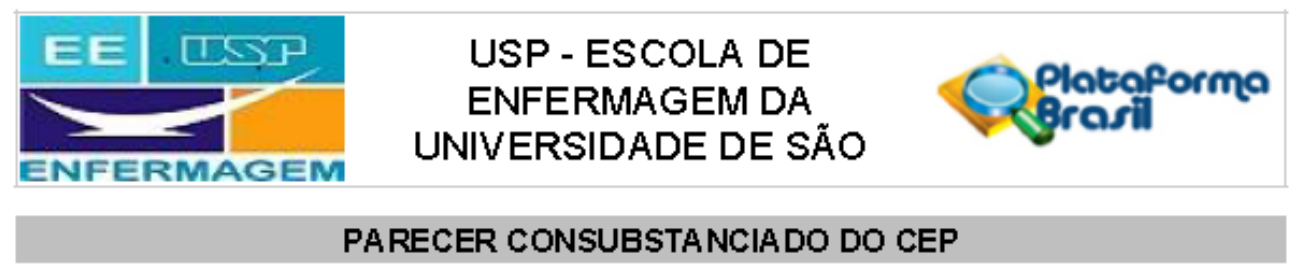

\section{DADOS DO PROJETO DE PESQUISA}

Título da Pesquisa Avaliaçẫo participativa de um serviço de atençẫo psicossocial em álcool e outras drogas

Pesquisador: RICARDO HENRIQUE SOARES

Área Temática:

Versão: 2

CAAE: 64443717.7 .0000 .5392

Instituição Proponente: Escola de Enfermagem da Universidade de Sẫo Paulo - EEUSP

Patrocinador Principal: Financiamento Próprio

\section{DADOS DO PARECER}

Número do Parecer: 1.969 .819

\section{Apresentação do Projeto:}

O presente projeto de pesquisa propỗe a realizaçẫo de uma avaliaçẫo em um Centro de Atençẫo Psicossocial em Álcool de Drogas do Município de Sấo Paulo (SP), visando avaliar a satisfaçấo dos profissionais, usuários e familiares com o serviço, bem como avaliar a percepçẫo de mudança desses mesmos usuários e familiares com o tratamento oferecido pelo serviço. Pretende-se realizar a avaliaçẫo mediante a abordagem qualitativa de pesquisa, tendo-se como referencial teórico-metodológico a avaliaçẫo de Quarta Geraçẫo proposta por Guba e Lincoln. A coleta e a análise dos dados serẫo empreendidas por meio do processo do Círculo Hermenêutico-dialétic o (Guba e Lincoln), no qual sẫo empregadas as técnicas de observaçẫo e de entrevistas individuais e grupais.

O tamanho da amostra será definido por saturaçã̃o, mas, na Plataforma Brasil, estima-se que o número de participantes de cada um dos 3 grupos seja igual a 30 .

\section{Objetivo da Pesquisa:}

Objetwo Geral

- Avaliar o Centro de Atençã̃o Psicossocial em Álc ool e outras Drogas Ermelino Matarazzo na perspectiva dos usuários, familiares e profissionais do serviço.

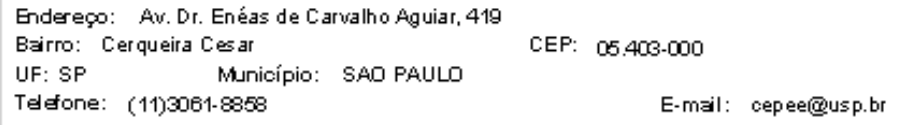




\section{EE प पर्P $\quad$ USP - ESCOLA DE ENFERMAGEM

Contruação do Parecer: 1.069819

Objetivos Específicos

- Avaliar a satisfaçẫo dos usuários, familiares e profissionais do Centro de Atençẫo Psicossocial em Álcool e outras Drogas Ermelino Matarazzo como serviço.

- Avaliar a perc epçã̃o de mudança dos usuários e familiares do Centro de Atençẫo Psicossocial em Álcool e outras Drogas Ermelino Matarazzo com o serviço.

\section{Avaliação dos Riscos e Benefícios:}

Considera-se o risco de desconforto emocional e de cansaço proveniente da partic ipaçẫo em entrevistas individual e grupal. o pesquisador esclarece que, em caso de desconforto, a entrevista poderá ser interrompida e o participante poderá ser encaminhado para atendimento.

Quanto aos benefícios, o pesquisador cita a utilidade da pesquisa para se construir uma "agenda" a ser oferecida aos gestores públicos para o aprimoramento dos serviços.

\section{Comentários e Considerações sobre a Pesquisa}

A ideia de conhecer a percepçẫo da qualidade de atendimento do CAPS-AD a partir dos pontos de vista de pacientes, seus familiares e profissionais da saúde é interessante e pode trazer informaçốes úteis para o aprimoramento dos serviços.

\section{Considerações sobre os Termos de apresentação obrigatória:}

O TCLE apresenta todas as informaçỗes necessárias.

Cronograma está de acordo com momento atual.

orçamento informa que o pesquisador arcará com as despesas da pesquisa.

Apresenta carta de autorizaçẫo da gerência regional da SMS-SP para submeter o projeto ao Comitê de Ética da SMS, que é a instituiçẫo cadastrada como co-participante.

\section{Recomendações:}

Nẫo há.

Conclusões ou Pendências e Lista de Inadequações:

Projeto aprovado.

Consideraçöes F inais a critério do CEP:

- Este CEP informa a necessidade de registro dos resultados parciais e finais na Plataforma Brasil;

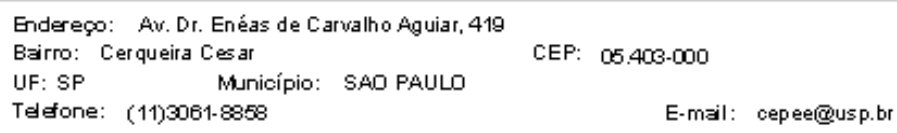




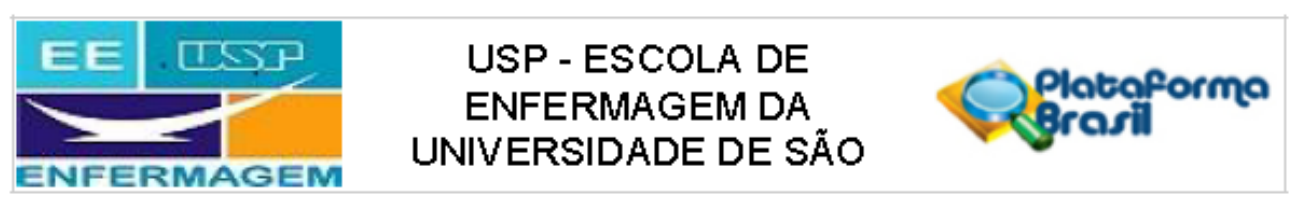

Continuação do Parecer: 1.969819

- Esta aprovaçẫo nẫo substitui a autoriz açẫo da instituiçẫo coparticipante, antes do início da coleta de dados.

Este parecer foi elaborado baseado nos documentos abaixo relacionados:

\begin{tabular}{|c|c|c|c|c|}
\hline Tipo Documento & Arquivo & Postagem & Autor & Situaç ẫo \\
\hline $\begin{array}{l}\text { Informaçỗes Básicas } \\
\text { do Projeto }\end{array}$ & $\begin{array}{l}\text { PB_INFORMAÇÖES_BASICAS_DO_P } \\
\text { ROJETO_850728.pdf }\end{array}$ & $\begin{array}{c}23 / 02 / 2017 \\
08: 11: 06\end{array}$ & & Ac eito \\
\hline $\begin{array}{l}\text { Projeto Detalhado i } \\
\text { Brochura } \\
\text { Investigador }\end{array}$ & $\begin{array}{l}\text { Projeto_Doutorado_Comite_Etica_Plataf } \\
\text { orma_Erasil_2017_Revisto.doc }\end{array}$ & $\begin{array}{c}23 / 02 / 2017 \\
08: 10: 24\end{array}$ & $\begin{array}{l}\text { RICARDO } \\
\text { HENRIQUE } \\
\text { SOARES }\end{array}$ & Ac eito \\
\hline $\begin{array}{l}\text { TCLE / Termos de } \\
\text { Assentimento / } \\
\text { Justificativa de } \\
\text { Ausência }\end{array}$ & TCLE_PlatBR_reformulado_PDF.podf & $\begin{array}{c}23 / 02 / 2017 \\
08: 09: 42\end{array}$ & $\begin{array}{l}\text { RICARDO } \\
\text { HENRIQUE } \\
\text { SOARES }\end{array}$ & Ac eito \\
\hline $\begin{array}{l}\text { TCLE / Termos de } \\
\text { Assentimento/ } \\
\text { Justificativa de } \\
\text { Ausência }\end{array}$ & TCLE_PlatBR_reformulado.doc & $\begin{array}{c}23 / 02 / 2017 \\
08: 08: 02\end{array}$ & $\begin{array}{l}\text { RICARDO } \\
\text { HENRIQUE } \\
\text { SOARES }\end{array}$ & Ac eito \\
\hline Folha de Rosto & Folha_de_Rosto_PlatBr.pdf & $\begin{array}{c}01 / 02 / 2017 \\
15: 30: 39 \\
\end{array}$ & $\begin{array}{l}\text { RICARDO } \\
\text { HENRIQUE }\end{array}$ & Ac eito \\
\hline $\begin{array}{l}\text { Declaraç ẫo de } \\
\text { Instituiçẫo e } \\
\text { Infraestrutura }\end{array}$ & $\begin{array}{l}\text { Autorizacao_Coordenadoria_Regional_S } \\
\text { aude_Leste.pdf }\end{array}$ & $\begin{array}{c}31 / 01 / 2017 \\
12: 35: 02\end{array}$ & $\begin{array}{l}\text { RICARDO } \\
\text { HENRIQUE } \\
\text { SOARES } \\
\end{array}$ & Ac eito \\
\hline
\end{tabular}

Situação do Parecer:

Aprovado

Necessita A preciação da CONEP:

Nẫo

SAO PAULO, 17 de Março de 2017

Assinado por:

Lisabelle Mariano Rossato

(Coordenador)

Endereço: Av. Dr. Enéas de Carvalho Aguiar, 419

Bairro: Cerqueira Cesar

CEP: $\quad 05.403-000$

UF: SP

Município: SAO PAULO

Telefone: (11)3061-8858

E-mail: cepee@usp.br 
ANEXO B - Parecer de Aprovação do Comitê de Ética em Pesquisa da Secretaria Municipal da Saúde de São Paulo

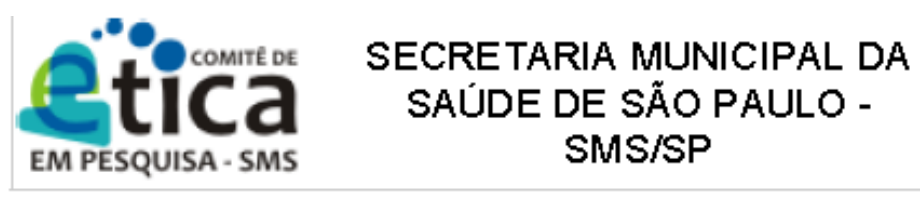

\section{PARECER CONSUBSTANCIADO DO CEP}

\section{Elaborado pela Instituição Coparticipante}

\section{DADOS DO PROJETO DE PESQUISA}

Título da Pesquisa Avaliaçẫo participativa de um serviço de atençẫo psicossocial em álcool e outras drogas

Pesquisador: RICARDO HENRIQUE SOARES

Área Temática:

Versão: 1

CAAE: 64443717.7 .3001 .0086

Instituição Proponente: Escola de Enfermagem da Universidade de Sấo Paulo - EEUSP

Patrocinador Principal: Financiamento Próprio

\section{DADOS DO PARECER}

Número do Parecer: 1.990 .622

\section{Apresentação do Projeto:}

A avaliaçẫo de serviços de saúde especializados no atendimento de pessoas com sofrimento mental decorrente do uso prejudicial de álcool e de outras drogas constitui-se como recurso hábil para aprimorar os serviços disponíveis, provendo subsídios para o aperfeiçoamento do sistema de saúde e para a eventual tomada de decisấo por parte dos gestores, no sentido de prosseguir ou reformular as prátic as e programas incorporados.

O presente projeto de pesquisa propỗe a realizaçẫo de uma avaliaçẫo em um Centro de Atençẫo Psicossocial em Álcool de Drogas do Município de Sẫo Paulo (SP), visando avaliar a satisfaçẫo dos profissionais, usuários e familiares com o serviço, bem como avaliar a percepçẫo de mudança desses mesmos usuários e familiares com o tratamento oferecido pelo serviço.

Pretende-se realizar a avaliaçẫo mediante a abordagem qualitativa de pesquisa, tendo-se como referencial teóric o-metodológico a avaliaçẫo de Quarta $\mathrm{G}$ eraç ẫo proposta por Guba e Lincoln.

A coleta e a análise dos dados serấo empreendidas por meio do processo do Círculo Hermenêutic odialétic o (Guba e Lincoln), no qual sẫo empregadas as técnicas de observaçẫo e de entrevistas individuais e grupais.

Tendo em vista que o projeto envolve a participaçẫo de seres humanos, a pesquisa será realizada conforme todos os procedimentos éticos exigidos pela legislaçẫo, com o consentimento livre e

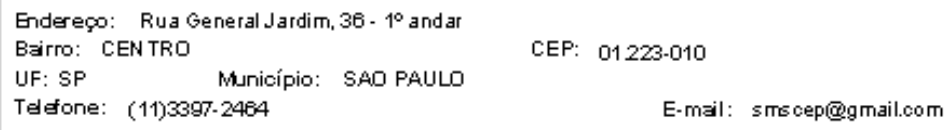




\section{*O comite de SECRETARIA MUNICIPAL DA SAÚDE DE SÃO PAULO - SMS/SP

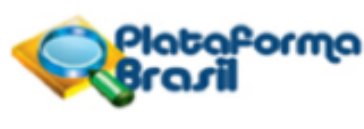

Conthuação do Parecer: 1.200622

esclarecido de todos os participantes, nos termos do preconizado pela Resoluçẫo 446/2012 do Conselho Nacional de Saúde.

\section{Objetivo da Pesquisa:}

Objetwo Primário:

Avaliar o Centro de Atençẫo Psicossocial emÁlcool e outras Drogas Ermelino M atarazzo na perspectiva dos usuários, familiares e profissionais do serviço.

Objetivo Secundário:

1. Avaliar a satisfaçẫo dos usuários, familiares e profissionais do Centro de Atençẫo Psicossocial em Álcool e outras Drogas Ermelino Matarazzo com o serviço;

2. Avaliar a percepçẫo de mudança dos usuários e familiares do Centro de Atençẫo Psicossocial em Álcool e outras Drogas Ermelino Matarazz o com o serviço.

\section{Avaliação dos Riscos e Benefícios:}

Riscos:

A participação na pesquisa pode causar aos participantes desconfortos físicos e emocionais provenientes, respectivamente, do eventual cansaço provocado pelo tempo nec essário para a realizaçẫo das entrevistas e pelo próprio teor dos questionamentos feitos durante as entrevistas.

Beneficios:

o presente estudo pretende oferecer uma agenda aos gestores públicos dos serviços de atenção psicossocial em álcool e outras drogas acerca dos interesses legítimos, próprios e compartilhados, das partes envolvidas nas intervençổes disponibiliz adas pelos serviços, subsidiando políticas públic as de saúde, açổes e serviços estratégicos, identificaç ẫo de fragilidades e de potencialidades do modelo assistencial, contribuindo para a melhoria da qualidade dos serviços prestados à população.

\section{Comentários e Consideraçôes sobre a Pesquisa}

A metodologia descrita está adequada aos objetivos propostos.

\section{Considerações sobre os Termos de apresentação obrigatória:}

A Folha de Rosto está corretamente preenchida, foram identificadas instituiçẫo proponente e coparticipante, autorizaçẫo para realizaçẫo da pesquisa foi adequadamente apresentada.

TCLE, Cronograma, orçamento detalhado e fonte financiadora estẫo adequados.

\section{Conclusões ou Pendências e Lista de Inadequações:}

Sem pendências ou inadequaçốes.

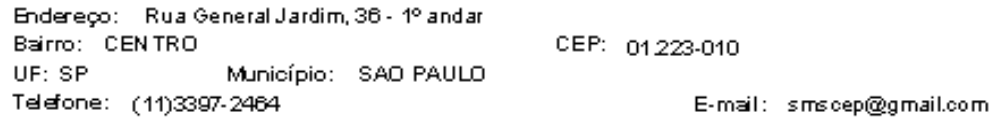




\section{*O comite de SECRETARIA MUNICIPAL DA SAÚDE DE SÃO PAULO - SMS/SP

Continuação do Parecer: 1.900622

\section{Consideraçōes F inais a critério do CEP:}

Para início da coleta dos dados, o pesquisador deverá se apresentar na mesma instância que autorizou a realizaçẫo do estudo (Coordenadoria, Supervisão, $8 M S / G a b$, etc).

Se o projeto prever aplic açẫo de TCLE, todas as páginas do documento deverẫo ser rubricadas pelo pesquisador e pelo voluntário e a última página assinada por ambos, conforme Carta Circular no 003/2011 da CONEPICNS.

Salientamos que o pesquisador deve desenvover a pesquisa conforme delineada no protocolo aprovado. Eventuais modificaçốes ou emendas ao protocolo devem ser apresentadas ao CEP de forma clara e sucinta, identificando a parte do protocolo a ser modificada e suas justific ativas. Lembramos que esta modificaçẫo nec essitará de aprovaçẫo ética do CEP antes de ser implementada.

De acordo com a Res. CNS 46612, o pesquisador deve apresentar os relatórios parciais e final através da Plataforma Brasil, ícone Notific aç ẫo. Uma cópia digital (CDIDVD) do projeto finalizado deverá ser enviada à instância que autorizou a realizaçẫo do estudo, via correio ou entregue pessoalmente, logo que o mesmo estiver concluído.

Este parecer foi edaborado baseado nos documentos abaixo relacionados:

\begin{tabular}{|c|c|c|c|c|}
\hline Tipo Documento & Arquivo & Postagem & Autor & Situaçẫo \\
\hline $\begin{array}{l}\text { Informaçốes Básicas } \\
\text { do Projeto }\end{array}$ & $\begin{array}{l}\text { PB_INFORMAÇÖES_BÁSICAS_DO_P } \\
\text { ROJETO } 850728 . p d f\end{array}$ & $\begin{array}{c}23 / 02 / 2017 \\
08: 11: 06\end{array}$ & & Aceito \\
\hline $\begin{array}{l}\text { Projeto Detalhado I } \\
\text { Brochura } \\
\text { Investigador }\end{array}$ & $\begin{array}{l}\text { Projeto_Doutorado_Comite_Etica_Plataf } \\
\text { orma_Erasil_2017_Revisto.doc }\end{array}$ & $\begin{array}{c}23 / 02 / 2017 \\
08: 10: 24\end{array}$ & $\begin{array}{l}\text { RICARDO } \\
\text { HENRIQUE } \\
\text { SOARES } \\
\end{array}$ & Ac eito \\
\hline $\begin{array}{l}\text { TCLE / Termos de } \\
\text { Assentimento / } \\
\text { Justificativa de } \\
\text { Ausência }\end{array}$ & TCLE_PlatBR_reformulado_PDF.pdf & $\begin{array}{c}23 / 02 / 2017 \\
08: 09: 42\end{array}$ & $\begin{array}{l}\text { RICARDO } \\
\text { HENRIQUE } \\
\text { SOARES }\end{array}$ & Ac eito \\
\hline $\begin{array}{l}\text { TCLE / Termos de } \\
\text { Assentimento / } \\
\text { Justificativa de } \\
\text { Ausência }\end{array}$ & TCLE_PlatBR_reformulado.doc & $\begin{array}{c}23 / 02 / 2017 \\
08: 08: 02\end{array}$ & $\begin{array}{l}\text { RICARDO } \\
\text { HENRIQUE } \\
\text { SOARES }\end{array}$ & Ac eito \\
\hline $\begin{array}{l}\text { Informaçỗes Básicas } \\
\text { do Projeto }\end{array}$ & $\begin{array}{l}\text { PB_INF ORMAÇŐES_BÁSICAS_DO_P } \\
\text { ROJETO_850728.pdf }\end{array}$ & $\begin{array}{c}05 / 02 / 2017 \\
10: 17: 27\end{array}$ & & Ac eito \\
\hline $\begin{array}{l}\text { TCLF / Termos de } \\
\text { Assentimento / } \\
\text { Justificativa de }\end{array}$ & TCLE_PlatBR.doc & $\begin{array}{c}05 / 02 / 2017 \\
10: 13: 50\end{array}$ & $\begin{array}{l}\text { RICARDO } \\
\text { HENRIQUE } \\
\text { SOARES } \\
\end{array}$ & Ac eito \\
\hline
\end{tabular}

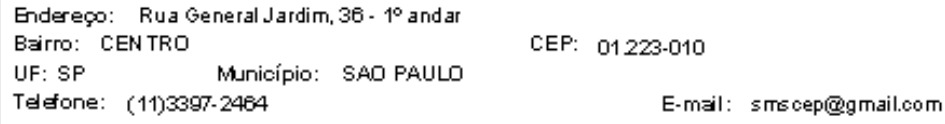




\section{SECRETARIA MUNICIPAL DA SAÚDE DE SÃO PAULO - SMS/SP}

Conthuação do Parecer: 1.000622

\begin{tabular}{|c|c|c|c|c|}
\hline Ausência & TCLE_PlatBR.doc & $\begin{array}{c}05 / 02 / 2017 \\
10: 13: 50 \\
\end{array}$ & \begin{tabular}{|l|} 
RICARDO \\
HENRIQUE
\end{tabular} & Ac eito \\
\hline $\begin{array}{l}\text { TCLE I Termos de } \\
\text { Assentimento ! } \\
\text { Justificativa de } \\
\text { Ausência }\end{array}$ & TCLE_PlatBR.pdf & $\begin{array}{c}05 / 02 / 2017 \\
10: 13: 19\end{array}$ & $\begin{array}{l}\text { RICARDO } \\
\text { HENRIQUE } \\
\text { SOARES }\end{array}$ & Ac eito \\
\hline $\begin{array}{l}\text { Projeto Detalhado I } \\
\text { Brochura } \\
\text { Investigador }\end{array}$ & $\begin{array}{l}\text { Projeto_Doutorado_Comite_Etica_Plataf } \\
\text { orma_Brasil_2017.doc }\end{array}$ & $\begin{array}{c}03 / 02 / 2017 \\
17: 45: 13\end{array}$ & $\begin{array}{l}\text { RICARDO } \\
\text { HENRIQUE } \\
\text { SOARES } \\
\end{array}$ & Ac eito \\
\hline $\begin{array}{l}\text { Informaçốes Básicas } \\
\text { do Projeto }\end{array}$ & $\begin{array}{l}\text { PB_INFORMAÇÖES_BÁSICAS_DO_P } \\
\text { ROJETO_850728.pdf }\end{array}$ & $\begin{array}{c}01 / 02 / 2017 \\
15: 35: 42 \\
\end{array}$ & & Ac eito \\
\hline Folha de Rosto & Folha_de_Rosto_PlatBr.pdf & $\begin{array}{c}01 / 02 / 2017 \\
15: 30: 39 \\
\end{array}$ & $\begin{array}{l}\text { RICARDO } \\
\text { HENRIQUE }\end{array}$ & Aceito \\
\hline $\begin{array}{l}\text { Declaraçẫo de } \\
\text { Instituiçấo e } \\
\text { Infraestrutura }\end{array}$ & $\begin{array}{l}\text { Autorizacao_Coordenadoria_Regional_S } \\
\text { aude_Leste.pdf }\end{array}$ & $\begin{array}{c}31 / 01 / 2017 \\
12: 35: 02\end{array}$ & $\begin{array}{l}\text { RICARDO } \\
\text { HENRIQUE } \\
\text { SOARES }\end{array}$ & Ac eito \\
\hline $\begin{array}{l}\text { Projeto Detalhado I } \\
\text { Brochura } \\
\text { Investigador }\end{array}$ & $\begin{array}{l}\text { Projeto_Doutorado_Comite_Etica_Plataf } \\
\text { orma_Brasil_2017.pdf }\end{array}$ & $\begin{array}{c}24 / 01 / 2017 \\
11: 16: 48\end{array}$ & $\begin{array}{l}\text { RICARDO } \\
\text { HENRIQUE } \\
\text { SOARES } \\
\end{array}$ & Ac eito \\
\hline
\end{tabular}

Situação do Parecer:

Aprovado

Necessita Apreciação da CONEP:

Nẫo

SAO PAULO, 30 de Março de 2017

Assinado por:

SIMONE MONGELLI DE F ANTINI

(Coordenador)

Endereco: Rua General Jardim, 36 - $1^{\circ}$ and ar

Bärro: CENTRO

UF: SP Município: SAO PAULO

CEP: $01223-010$

Telefone: (11)3397-2464

E-mail： smscep@gmail.com 